Prepared in cooperation with the U.S. Department of Agriculture, Farm Service Agency

\title{
Saturated Thickness and Water in Storage in the High Plains Aquifer, 2009, and Water-Level Changes and Changes in Water in Storage in the High Plains Aquifer, 1980 to 1995, 1995 to 2000, 2000 to 2005, and 2005 to 2009
}

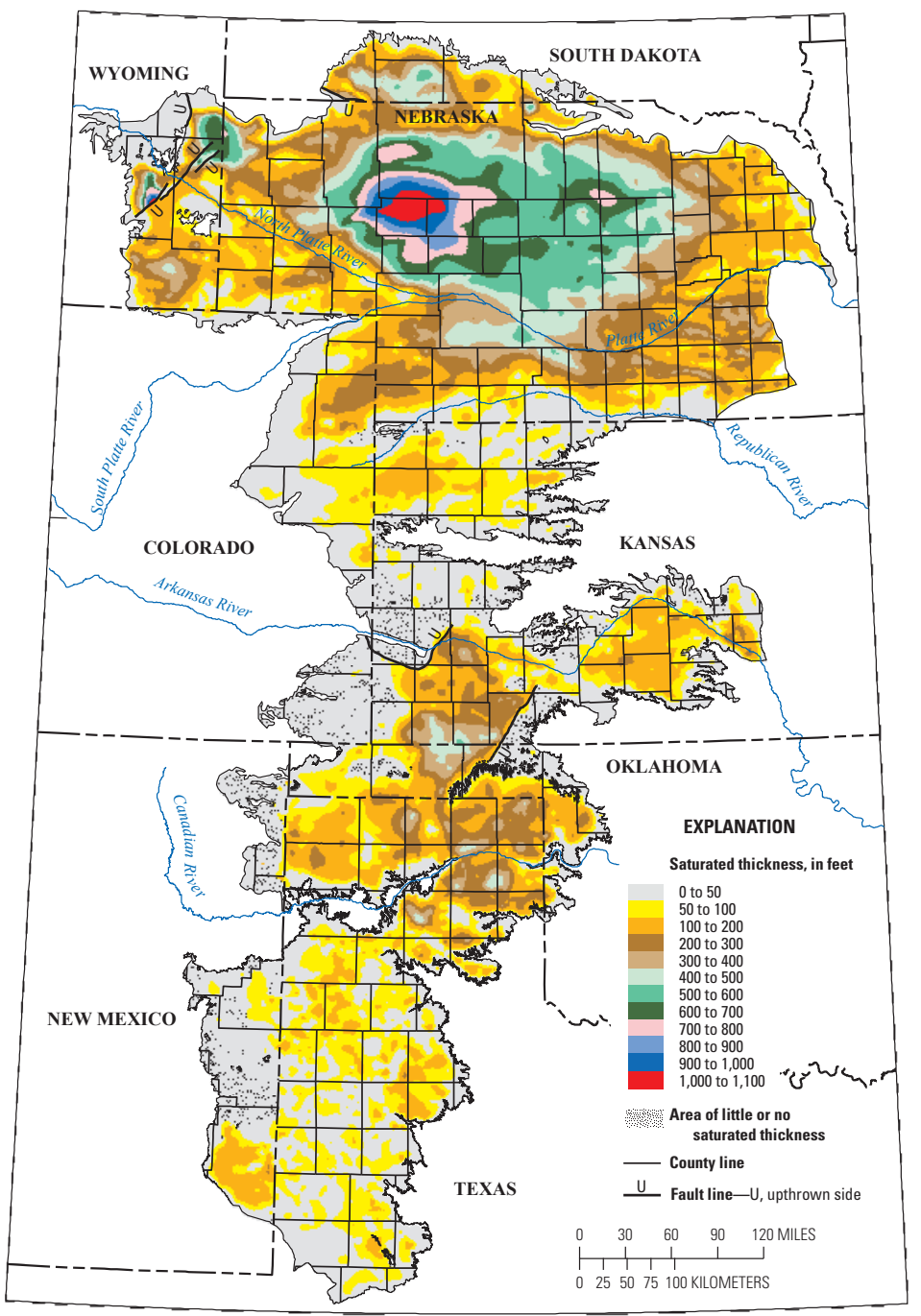

Scientific Investigations Report 2012-5177 
Cover: Figure 1 from the report with modifications. 


\section{Saturated Thickness and Water in Storage in the High Plains Aquifer, 2009, and Water- Level Changes and Changes in Water in Storage in the High Plains Aquifer, 1980 to 1995, 1995 to 2000, 2000 to 2005, and 2005 to 2009}

By Virginia L. McGuire, Kris D. Lund, and Brenda K. Densmore

Prepared in cooperation with the U.S. Department of Agriculture, Farm Service Agency

Scientific Investigations Report 2012-5177 


\title{
U.S. Department of the Interior \\ KEN SALAZAR, Secretary \\ U.S. Geological Survey \\ Marcia K. McNutt, Director
}

\author{
U.S. Geological Survey, Reston, Virginia: 2012
}

For more information on the USGS - the Federal source for science about the Earth, its natural and living resources, natural hazards, and the environment, visit http://www.usgs.gov or call 1-888-ASK-USGS.

For an overview of USGS information products, including maps, imagery, and publications, visit http://www.usgs.gov/pubprod

To order other USGS information products, visit http://store.usgs.gov

Any use of trade, firm, or product names is for descriptive purposes only and does not imply endorsement by the U.S. Government.

Although this information product, for the most part, is in the public domain, it also may contain copyrighted materials as noted in the text. Permission to reproduce copyrighted items must be secured from the copyright owner.

Suggested citation:

McGuire, V.L., Lund, K.D., and Densmore, B.K., 2012, Saturated thickness and water in storage in the High Plains aquifer, 2009, and water-level changes and changes in water in storage in the High Plains aquifer, 1980 to 1995, 1995 to 2000, 2000 to 2005, and 2005 to 2009: U.S. Geological Survey Scientific Investigations Report 2012-5177, 28 p. 


\section{Contents}

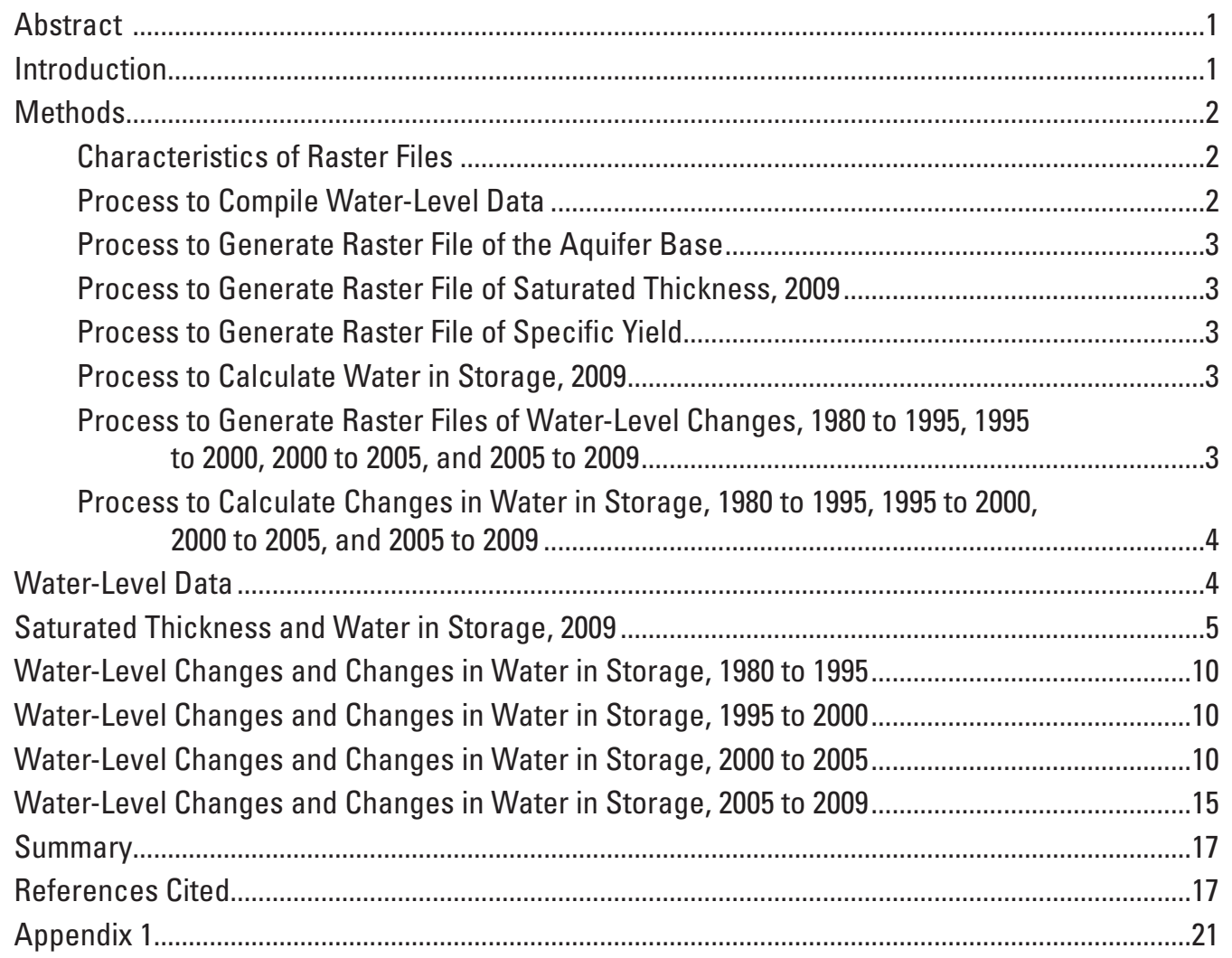

\section{Figures}

1. Map showing saturated thickness of the High Plains aquifer, 2009 .................................6

2. Map showing specific yield of the High Plains aquifer...................................................

3. Map showing water-level changes in the High Plains aquifer, 1980 to $1995 . \ldots \ldots \ldots \ldots \ldots \ldots . . . .11$

4. Map showing water-level changes in the High Plains aquifer, 1995 to $2000 \ldots \ldots \ldots \ldots \ldots \ldots . . . .13$

5. Map showing water-level changes in the High Plains aquifer, 2000 to 2005....................14

6. Map showing water-level changes in the High Plains aquifer, 2005 to 2009....................16 


\section{Tables}

1. Number of wells used in this report to estimate water-level changes in the High Plains aquifer for the water-level comparison periods from 1980 to 1995, 1995 to 2000,2000 to 2005, and 2005 to 2009, and number of wells used in this report to estimate saturated thickness of the High Plains aquifer, 2009, by State and in total........5

2. Number of wells screened in the High Plains aquifer in New Mexico and measured in winter or spring, 1995 to 2010; used to estimate saturated thickness, 2009; and used to estimate water level for 1980, 1995, 2000, 2005, and 2009, by water year.

3. Distribution of aquifer area, area of little or no saturated thickness, and volume of saturated material, High Plains aquifer, 2009, by State and in total.

4. Area-weighted, average specific yield using average-mapped specific yield generated from a contour map of specific yield ranges of the High Plains aquifer, by State and in total, with and without areas of little or no saturated thickness .9

5. Distribution of water in storage in the High Plains aquifer, 1980, 2000, and 2009, by State and in total, as calculated in this report and in previous reports

6. Distribution of area-weighted, average water-level changes in the High Plains aquifer, 1980 to 1995, 1995 to 2000, 2000 to 2005, and 2005 to 2009, by State and in total, as calculated in this report and in previous reports...

7. Distribution of changes in water in storage in the High Plains aquifer, 1980 to 1995 , 1995 to 2000, 2000 to 2005, and 2005 to 2009, by State and in total, as calculated in this report and in previous reports 


\section{Conversion Factors}

Inch/Pound to SI

\begin{tabular}{lcl}
\hline & Multiply & By obtain \\
\hline foot $(\mathrm{ft})$ & Length & meter $(\mathrm{m})$ \\
mile (mi) & 0.3048 & kilometer $(\mathrm{km})$ \\
\hline & 1.609 & \\
\hline acre & Area & square meter $\left(\mathrm{m}^{2}\right)$ \\
square foot $\left(\mathrm{ft}^{2}\right)$ & 4,047 & square meter $\left(\mathrm{m}^{2}\right)$ \\
square mile $\left(\mathrm{mi}^{2}\right)$ & 0.09290 & square kilometer $\left(\mathrm{km}^{2}\right)$ \\
\hline & 2.590 & \\
\hline gallon $(\mathrm{gal})$ & Volume & liter $(\mathrm{L})$ \\
gallon $(\mathrm{gal})$ & 3.785 & cubic meter $\left(\mathrm{m}^{3}\right)$ \\
cubic foot $\left(\mathrm{ft}^{3}\right)$ & 0.003785 & cubic meter $\left(\mathrm{m}^{3}\right)$ \\
acre-foot $(\mathrm{acre}-\mathrm{ft})^{*}$ & 0.02832 & cubic meter $\left(\mathrm{m}^{3}\right)$ \\
\hline
\end{tabular}

${ }^{*}$ One acre-foot of water is equivalent to the volume of water that would cover 1 acre $\left(43,560 \mathrm{ft}^{2}\right)$ to a depth of 1 foot $\left(325,851\right.$ gallons or $\left.43,560 \mathrm{ft}^{3}\right)$.

Vertical coordinate information is referenced to the National Geodetic Vertical Datum of 1929 (NGVD 29).

Horizontal coordinate information is referenced to the North American Datum of 1983 (NAD 83).

Altitude, as used in this report, refers to distance above the vertical datum. 



\title{
Saturated Thickness and Water in Storage in the High Plains Aquifer, 2009, and Water-Level Changes and Changes in Water in Storage in the High Plains Aquifer, 1980 to 1995, 1995 to 2000, 2000 to 2005, and 2005 to 2009
}

\author{
By Virginia L. McGuire, Kris D. Lund, and Brenda K. Densmore
}

\section{Abstract}

The High Plains aquifer underlies about 112 million acres (about 175,000 square miles) in parts of eight StatesColorado, Kansas, Nebraska, New Mexico, Oklahoma, South Dakota, Texas, and Wyoming. Water levels declined in parts of the High Plains aquifer soon after the onset of substantial irrigation with groundwater (about 1950). This report presents the volume of saturated aquifer material and drainable water in storage in the High Plains aquifer in 2009; water-level changes in the High Plains aquifer from 1980 to 1995,1995 to 2000, 2000 to 2005, and 2005 to 2009; and changes in the volume of drainable water in storage in the aquifer from 1980 to 1995 , 1995 to 2000,2000 to 2005 , and 2005 to 2009 . The volume data were calculated from raster files with a cell size of about 62 acres.

The volume of water in storage in the High Plains aquifer in 2009 is estimated at about 3.0 billion acre-feet. Areaweighted, average water-level changes for the aquifer were declines of 2.0 feet from 1980 to $1995,1.3$ feet from 1995 to 2000, 2.8 feet from 2000 to 2005, and 1.0 foot from 2005 to 2009. Estimated changes in water in storage were declines of 36.0 million acre-feet from 1980 to 1995, 23.5 million acrefeet from 1995 to 2000, 46.7 million acre-feet from 2000 to 2005, and 18.3 million acre-feet from 2005 to 2009.

\section{Introduction}

The High Plains aquifer underlies about 112 million acres [about 175,000 square miles $\left(\mathrm{mi}^{2}\right)$ ] in parts of eight StatesColorado, Kansas, Nebraska, New Mexico, Oklahoma, South Dakota, Texas, and Wyoming (Qi, 2010; Weeks and Gutentag, 1981). Groundwater in the High Plains aquifer generally is under unconfined conditions; that is, the aquifer, from a regional perspective, has a water table where, by definition, the water pressure is atmospheric (Weeks and Gutentag, 1981). The saturated thickness of the aquifer (defined as the distance from the water table to the base of the aquifer) in 2000 ranged from less than 50 feet (ft) to about 1,200 ft (McGuire and others, 2003). Gutentag and others (1984) reported that, in a few parts of the aquifer, the water table is discontinuous; these areas are labeled as "areas of little or no saturated thickness." According to Gutentag and others (1984), wells drilled in these areas of little or no saturated thickness likely will not yield water unless the well penetrates saturated sediment in either buried channels or depressions in the bedrock.

The area overlying the High Plains aquifer is one of the primary agricultural regions of the Nation. In parts of the area, farmers and ranchers began extensive pumping of groundwater for irrigation in the 1930s and 1940s. Estimated irrigated acreage in the area overlying the High Plains aquifer increased from 1940 to 1980, but did not change substantially from 1980 to $2005-2.1$ million acres in $1949,13.7$ million acres in 1980 , 13.9 million acres in 1997, 12.7 million acres in 2002, and 15.5 million acres in 2005 (Heimes and Luckey, 1982; Thelin and Heimes, 1987; U.S. Department of Agriculture, 1999 and 2004; Kenny and others, 2009). In 2005, irrigated acres overlaid 14 percent of the aquifer area, not including the areas with little or no saturated thickness (Kenny and others, 2009).

About every 5 years, groundwater withdrawals for irrigation and other uses are compiled from water-use data and reported by the U.S. Geological Survey (USGS) and State agencies. Groundwater withdrawals from the High Plains aquifer for irrigation increased from 4 to 19 million acre-feet (acre-ft) from 1949 to 1974; groundwater withdrawals for irrigation in 1980, 1985, 1990, and 1995 were 4 to 18 percent less than withdrawals for irrigation in 1974 (Heimes and Luckey, 1982; U.S. Geological Survey, 2008). Groundwater withdrawals from the High Plains aquifer for irrigation were 21 million acre-ft in 2000 and 19 million acre-ft in 2005 (Maupin and Barber, 2005; U.S. Geological Survey, 2008; Kenny and others, 2009).

Water-level declines began in parts of the High Plains aquifer soon after the onset of substantial pumpage of groundwater for irrigation - about 1950 (Gutentag and others, 1984). By 1980, water levels in the High Plains aquifer in parts of 
Texas, Oklahoma, and southwestern Kansas had declined more than $100 \mathrm{ft}$ (Luckey and others, 1981).

Long-term water-level changes in the aquifer result from an imbalance between discharge and recharge. Discharge from the High Plains aquifer primarily consists of groundwater withdrawals for irrigation, but also includes groundwater withdrawals for public supply and other uses, evapotranspiration where the water table is near land surface, and seepage to streams, springs, and other surface-water bodies where the water table intersects the land surface (Maupin and Barber, 2005). Recharge to the aquifer primarily is from precipitation, with other sources of recharge including seepage from streams, canals, and reservoirs, and irrigation return flows (Luckey and Becker, 1999). Water-level declines may result in increased costs for groundwater withdrawals because of increased pumping lift and decreased well yields (Taylor and Alley, 2001). Water-level declines also can affect groundwater availability for well owners, stream flows, and near-stream (riparian) habitat areas (Alley and others, 1999).

The purpose of this report is to present the saturated thickness and volume of drainable water in storage in the High Plains aquifer in 2009; water-level changes in the High Plains aquifer from 1980 to 1995,1995 to 2000,2000 to 2005, and 2005 to 2009; and changes in the volume of drainable water in storage in the aquifer from 1980 to 1995,1995 to 2000, 2000 to 2005 , and 2005 to 2009 . Water-volume data were generated as raster files with a cell size of about 62 acres, to allow for overlaying those data with other data at the farm-field scale, given that the accuracy of the interpolations are dependent on the density of water-level data. In addition, the interpolation process used to generate the raster file in this report result in cell values that are generally similar to, but commonly not exactly equal to, values based on water-level measurements.

Water levels used in this report generally were measured in wells in winter or early spring. During that period, irrigation wells typically are not pumping, and water levels generally have recovered from pumping during the previous irrigation season. Water levels were not used in this report if water levels appeared to be affected by pumping in the measured well or in nearby wells. Drainable water in storage is the fraction of water in the aquifer that will drain by gravity and can be withdrawn by wells. Drainable water in storage is referred to as "water in storage" in this report. Remaining water in the aquifer is held to the aquifer material by capillary forces and generally cannot be withdrawn by wells.

\section{Methods}

\section{Characteristics of Raster Files}

The water-volume data for this report are presented as raster files, which were generated using a geographic information system (GIS). The specific GIS program used was ESRI ${ }^{\circledR}$ Arc/Info ${ }^{\mathrm{TM}}$ version 9.3 (Environmental Systems Research
Institute, 1992 and variously dated). The raster files are in Albers equal-area conic projection with a North American Datum of 1983 (NAD 83). The cell size for all raster files was about 62 acres [ 500 meters $(\mathrm{m})$ by $500 \mathrm{~m}$ ]. The cell-value unit for water-level change was feet. The cell-value unit for change in water in storage was square meter-feet $\left(\mathrm{m}^{2}-\mathrm{ft}\right)$; water in storage values were summarized in this report in units of million acre-ft. The cell-value unit for specific yield was a dimensionless decimal fraction (less than 1). Raster files in this report are saturated thickness, 2009; specific yield; and water-level changes from 1980 to 1995,1995 to 2000,2000 to 2005 , and 2005 to 2009.

\section{Process to Compile Water-Level Data}

Water-level data used in this report generally were measured with an electric or steel tape using methods similar to those described by Cunningham and Schalk (2011). Most of the wells were measured manually one to two times per water year. The water year starts in October in the prior year and ends in September in the given year. Generally, if a well was measured one time per water year, the well was measured in the winter or early spring, or, if a well was measured two times per water year, the well was measured in winter or early spring and in the late fall. Some wells were measured nearly continuously by using instrumentation (data recorders with sensors or floats) installed in the well that recorded the water level periodically (generally every 15 to 60 minutes) (Cunningham and Schalk, 2011). Water-level data used to map water-level changes were compiled for each of the specified water years $(1980,1995,2000,2005$, and 2009) from data used in previous reports on water-level changes in the High Plains aquifer (U.S. Geological Survey, 2012). Available water-level data for each well were reviewed to select a static water level for each applicable water year (that is, a water level that has recovered from pumping in the previous irrigation season) and a water level that is consistent with water levels in neighboring wells. If a static water level was not available for a given well for the specified water year, the water-level data for that well for the specified water year were not used in this report.

In all eight States underlain by the High Plains aquifer, available water levels for 1980 were compiled by Weeks and Gutentag (1981). The 1980 water levels generally were measured after the irrigation season in 1979 and before the irrigation season in 1980 (that is, in water year 1980).

In seven of the eight States that are underlain by the High Plains aquifer-Colorado, Kansas, Nebraska, Oklahoma, South Dakota, Texas, and Wyoming - most water-level data used in this report were from wells measured annually. The estimated 2009 saturated thickness of the High Plains aquifer in these seven States was calculated using water levels measured in water year 2009. Water-level changes for the various water-level comparison periods (1980 to 1995, 1995 to 2000, 2000 to 2005, and 2005 to 2009) in these seven States were calculated from wells with a static water level for water years at the beginning and end of each period. 
In areas underlain by the High Plains aquifer in New Mexico, some wells were measured only once every 5 years. In this report, to expand the number of wells in New Mexico for a specified year, the latest static water level measured in the specified year, and in other years, was used to estimate the water level for that well for the specified year. The estimated 2009 saturated thickness of the High Plains aquifer in New Mexico was calculated using the latest available static water-level measurement from 2005 to 2009 for each well. To estimate change in water levels for wells in New Mexico, the most recent water-level measurement from 1995, 1996, or 1997 was selected as the estimated water level for 1995; the most recent water-level measurement from 2000, 2001, and 2002 was selected as the estimated water level for 2000; the most recent water-level measurement from 2005, 2006, and 2007 was selected as the estimated water level for 2005; and the most recent water-level measurement from 2009 and 2010 was selected as the estimated water level for 2009. In New Mexico, water-level change for the various water-level comparison periods (1980 to 1995, 1995 to 2000, 2000 to 2005, and 2005 to 2009) was calculated for wells with an estimated static water level at the beginning and end of each period.

\section{Process to Generate Raster File of the Aquifer Base}

Contours of the altitude of the base of the aquifer used for a saturated thickness map for the year 2000 (McGuire and others, 2003) were based on available base-of-aquifer maps (Weeks and Gutentag, 1981; Borman and Meredith, 1983; Borman and others, 1984; Hart and McAda, 1985; Juracek and Hansen, 1995; Luckey and Becker, 1999; Houston and others, 2003). The base-of-aquifer contours from those published maps were reviewed and reconciled in areas where they differed. The base-of-aquifer contours were converted to a raster file using the GIS command "topogrid" (Environmental Systems Research Institute, 1992 and variously dated).

\section{Process to Generate Raster File of Saturated Thickness, 2009}

Saturated thickness in 2009 was mapped using calculated saturated thickness for each well with a measured or estimated water level for 2009. Before calculating the saturated thickness for each well with a static water level in 2009, (1) the altitude of the aquifer base was estimated using the GIS command "latticespot" (Environmental Systems Research Institute, 1992 and variously dated) and the raster file of the aquifer base, and (2) the altitude of the water table in 2009 was calculated by subtracting depth to water from land surface from the landsurface elevation (U.S. Geological Survey, 2011). Saturated thickness then was calculated by subtracting the altitude of the aquifer base from the altitude of the water table in 2009. In areas with minimal water-level data and irrigation, such as in northwestern Wyoming, previously published contours of saturated thickness were assumed to represent current (2009) conditions (Weeks and Gutentag, 1981; Qi and others, 2002). The saturated thickness raster file was generated using the GIS command "topogrid" (Environmental Systems Research Institute, 1992 and variously dated); inputs to the "topogrid" command were the saturated thickness values for each well and previously published contours of saturated thickness. The resultant raster file was examined in areas with minimal waterlevel data and irrigation using the GIS command "con;" if the cell value was greater than or less than the range of the corresponding saturated thickness contours in previously published maps, the cell value was changed to the mid-range of the corresponding saturated thickness contours of those maps.

\section{Process to Generate Raster File of Specific Yield}

Specific yield of the aquifer is needed to calculate water in storage. Specific yield was mapped for the High Plains aquifer from area-weighted, average specific yields derived from lithologic logs for selected wells or test holes generally drilled to the base of the aquifer (Gutentag and others, 1984). A specific yield raster file was created from a contour map of specific yield ranges in the High Plains aquifer (Gutentag and others, 1984; Cederstrand and Becker, 1998). The GIS command "polygrid" (Environmental Systems Research Institute, 1992 and variously dated) was used to convert the average of the assigned range for the specific yield polygons to a raster file of the area. The specific yield value of cells in this raster file of specific yield is hereafter referred to as the averagemapped specific yield value.

\section{Process to Calculate Water in Storage, 2009}

Water in storage in the High Plains aquifer in 2009 was calculated for each cell by multiplying the raster value of saturated thickness for 2009, times the raster value of averagemapped specific yield, times a conversion factor to convert $\mathrm{m}^{2} \mathrm{ft}$ to million acre-ft. Summaries of water in storage by State and by county were calculated by aggregating the raster values for water in storage, 2009, for the aquifer area, not including the areas of "little or no saturated thickness" as delineated by Gutentag and others (1984).

\section{Process to Generate Raster Files of Water-Level Changes, 1980 to 1995, 1995 to 2000, 2000 to 2005, and 2005 to 2009}

The raster file of water-level changes in the High Plains aquifer from 1980 to 1995 was generated using the following approach: 
1. Water-level data for all wells with static water-level data for 1980 and 1995 were compiled.

2. An attribute, labeled "FSA_delta80_95," was calculated as water level, 1980, minus water level, 1995, for each well and added to the point data set of water-level change, 1980 to 1995.

3. An attribute, labeled "beginval," was added to the published contours of water-level change, 1980 to 1995 (McGuire and Sharpe, 1997); "beginval” was populated with the beginning range value of the contour. For example, for contours of a $5 \mathrm{ft}$ to $10 \mathrm{ft}$ rise, "beginval" was set to $5 \mathrm{ft}$; for contours of a $-5 \mathrm{ft}$ to $-10 \mathrm{ft}$ decline, "beginval" was set to $-5 \mathrm{ft}$.

4. The GIS command "topogrid" (Environmental Systems Research Institute, 1992 and variously dated) was used to generate an initial raster file of water-level change. Inputs included the point data set of water-level change for 1980 to 1995 (attribute "FSA_delta80_95") and modified contours of water-level change, 1980 to 1995 (attribute "beginval").

5. The GIS command "contour" (Environmental Systems Research Institute, 1992 and variously dated) was applied to the initial raster output from topogrid to generate the water-level change contours (attribute "contour") for the $-3 \mathrm{ft}$ and $3 \mathrm{ft}$ contours of water-level change, 1980 to 1995. In areas with little water-level data, contours from McGuire and Sharpe (1997) and the $-3 \mathrm{ft}$ and $3 \mathrm{ft}$ contours were modified manually to make the interpolation more realistic. Contours were built as polygons and the polygon attribute "startval" was set equal to one for polygons formed by the $-3 \mathrm{ft}$ and $3 \mathrm{ft}$ contours and set to zero for all other polygons. The polygons formed by the $-3 \mathrm{ft}$ and $3 \mathrm{ft}$ contours delineate areas of no substantial water-level change on the map. The GIS command "polygrid" was used to generate a raster file of no substantial change using the polygon attribute "startval."

6. The GIS command "topogrid" (Environmental Systems Research Institute, 1992 and variously dated) was used to generate a raster file of water-level changes, 1980 to 1995. Inputs to the topogrid process included a point data set of water-level change for 1980 to 1995 (attribute "FSA_delta80_95") and the modified contours of waterlevel change, 1980 to 1995 (attribute "contour"). This raster file was modified using the GIS function "con" to change the cell values to null in areas where the aquifer is not present (Gutentag and others, 1984) and to change the cell value to zero in areas of no substantial change. This modified raster file was used to show water-level changes from 1980 to 1995 in this report.

7. The final raster file from step 6 was further modified using the GIS function "con" to change the cell values to null in the areas of little or no saturated thickness as described by Gutentag and others (1984). This modified raster file was used for statistical analysis and to calculate summary tables in this report.

The raster files of water-level change in the High Plains aquifer for 1995 to 2000, 2000 to 2005, and 2005 to 2009 were calculated using a similar approach as previously described; however, because contours for water-level change were not available for the entire High Plains aquifer for these selected time periods, contours of water-level change were generated from water-level-change data using the GIS command "topogrid" (Environmental Systems Research Institute, 1992 and variously dated) and then modified manually. Areas deemed to have no substantial change for the 1995 to 2000 , 2000 to 2005, and 2005 to 2009 time periods were those with water-level change between -1 ft and $1 \mathrm{ft}$. The water-level change point data and modified contours of water-level change were input to the second run of the GIS command "topogrid" to generate the revised raster file of water-level change. The water-level change value in areas of no substantial change was set to 0 using the GIS command "con." The definition of areas having no substantial change for the 1995 to 2000, 2000 to 2005 , and 2005 to 2009 time periods was set to a smaller value $(-1 \mathrm{ft}$ to $1 \mathrm{ft}$ ) than for the 1980 to 1995 time period $(-3 \mathrm{ft}$ to $3 \mathrm{ft}$ ) because the durations of the time periods were shorter ( 4 to 5 years versus 15 years) and the magnitudes of the waterlevel changes were smaller.

\section{Process to Calculate Changes in Water in Storage, 1980 to 1995, 1995 to 2000, 2000 to 2005, and 2005 to 2009}

Changes in water in storage in the High Plains aquifer in the 1980 to 1995,1995 to 2000,2000 to 2005 , and 2005 to 2009 time periods were calculated by multiplying the raster values of water-level change for each period by the raster values of average-mapped specific yield and by a conversion factor to convert $\mathrm{m}^{2} \mathrm{ft}$ to million acre-feet. Totals of changes in water in storage by State and county were calculated by aggregating the values for change in water in storage for each period.

\section{Water-Level Data}

Water-level data used in this report were provided by the following Federal, State, and local entities through data files, and loaded into the U.S. Geological Survey National Water Information System (U.S. Geological Survey, 2011); the sources for the water-level data are noted below:

- Colorado: Division of Water Resources (also known as the Office of the State Engineer); 
- Kansas: Department of Agriculture-Division of Water Resources and Kansas Geological Survey (Kansas Geological Survey, 2010);

- Nebraska: Central Nebraska Public Power and Irrigation District, applicable Natural Resources Districts, and the University of Nebraska-Lincoln, Conservation and Survey Division;

- New Mexico: Office of the State Engineer;

- Oklahoma: Water Resources Board;

- South Dakota: Department of Environment and Natural Resources;

- Texas: Groundwater Conservation Districts and the Water Development Board (Texas Water Development Board, 2010);

- Wyoming: State Engineer's Office; and

- Federal: Bureau of Reclamation, U.S. Fish and Wildlife Service, and U.S. Geological Survey offices in Colorado, Kansas, Nebraska, New Mexico, Oklahoma, South Dakota, Texas, and Wyoming (U.S. Geological Survey, 2011).

The number of water-level measurements in wells that are screened in the High Plains aquifer vary annually. To estimate the saturated thickness of the High Plains aquifer in Colorado, Kansas, Nebraska, Oklahoma, South Dakota, Texas, and Wyoming in 2009, this report uses 8,690 water levels measured during water year 2009 (table 1). To estimate the saturated thickness of the High Plains aquifer in New Mexico in 2009, this report uses water levels measured in 2009 and, for wells not measured in 2009, the most recent water-level data collected from 2005 to 2008. In New Mexico, 307 wells were used to estimate saturated thickness in 2009 (table 1); 246 of those wells were measured in at least one of the water years from 2005 to 2008 , and 61 of those wells were measured in water year 2009 (table 2).

To estimate water-level changes in the applicable waterlevel comparison periods, water-level data were compiled for 1980, 1995, 2000, 2005, and 2009. The 1980 water levels generally were measured in water year 1980 (Weeks and Gutentag, 1981) in the eight States that overlie the aquifer. For wells located in Colorado, Kansas, Nebraska, Oklahoma, South Dakota, Texas, and Wyoming, the 1995, 2000, 2005, and 2009 water levels for the water-level comparison periods were measured in the corresponding water years (table 1). For wells located in New Mexico, the 1995, 2000, 2005, and 2009 water levels for the water-level comparison periods were measured in the corresponding water year and in one or two of the following water years (table 2).

\section{Saturated Thickness and Water in Storage, 2009}

The volume of saturated material in the High Plains aquifer in 2009 was estimated from the saturated thickness map of the aquifer for 2009 (fig. 1). The volume of saturated material in the aquifer in 2009 ranged from 200 million acre-ft in New Mexico to 13,200 million acre-ft in Nebraska (table 3). Water in storage in the High Plains aquifer in 2009 was calculated

Table 1. Number of wells used in this report to estimate water-level changes in the High Plains aquifer for the water-level comparison periods from 1980 to 1995, 1995 to 2000, 2000 to 2005, and 2005 to 2009, and number of wells used in this report to estimate saturated thickness of the High Plains aquifer, 2009, by State and in total.

\begin{tabular}{|c|c|c|c|c|c|}
\hline \multirow{2}{*}{ State } & \multicolumn{4}{|c|}{$\begin{array}{l}\text { Number of wells used to estimate water-level } \\
\text { changes by water-level comparison period }\end{array}$} & \multirow{2}{*}{$\begin{array}{l}\text { Number of wells } \\
\text { used to estimate } \\
\text { saturated thickness, } \\
2009\end{array}$} \\
\hline & $\begin{array}{c}1980 \text { to } \\
1995\end{array}$ & $\begin{array}{c}1995 \text { to } \\
2000\end{array}$ & $\begin{array}{c}2000 \text { to } \\
2005\end{array}$ & $\begin{array}{c}2005 \text { to } \\
2009\end{array}$ & \\
\hline Colorado & 515 & 492 & 475 & 318 & 345 \\
\hline Kansas & 883 & 827 & 1,031 & 955 & 1,708 \\
\hline Nebraska & 1,961 & 2,453 & 3,310 & 3,573 & 3,676 \\
\hline New Mexico & 236 & 329 & 252 & 72 & 307 \\
\hline Oklahoma & 198 & 151 & 105 & 124 & 132 \\
\hline South Dakota & 45 & 55 & 83 & 88 & 85 \\
\hline Texas & 1,925 & 1,630 & 1,948 & 2,256 & 2,491 \\
\hline Wyoming & 20 & 34 & 44 & 43 & 253 \\
\hline High Plains aquifer & 5,783 & 5,971 & 7,248 & 7,429 & 8,997 \\
\hline
\end{tabular}




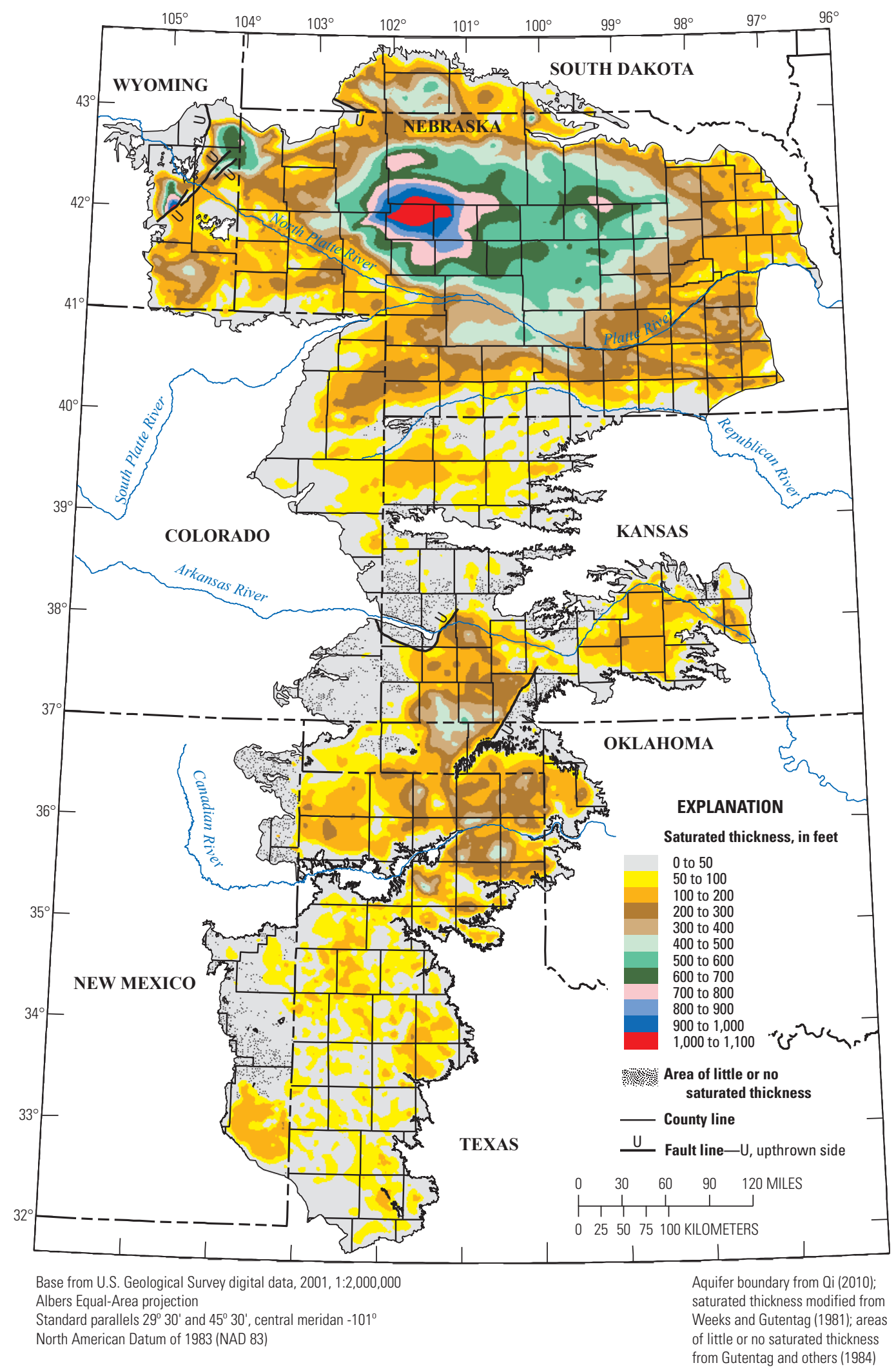

Figure 1. Saturated thickness of the High Plains aquifer, 2009. 
Table 2. Number of wells screened in the High Plains aquifer in New Mexico and measured in winter or spring, 1995 to 2010; used to estimate saturated thickness, 2009; and used to estimate water level for 1980, 1995, 2000, 2005, and 2009, by water year.

[All wells have a static water level in winter or spring of the specified year; water year, October of the prior year through September of the given year; --, not applicable]

\begin{tabular}{|c|c|c|c|c|c|c|c|c|c|c|}
\hline \multirow{4}{*}{$\begin{array}{l}\text { Water } \\
\text { year }\end{array}$} & \multirow{4}{*}{$\begin{array}{c}\text { Number of } \\
\text { wells measured } \\
\text { in winter or } \\
\text { spring, by water } \\
\text { year }\end{array}$} & \multirow{4}{*}{$\begin{array}{l}\text { Number of wells } \\
\text { used to estimate } \\
\text { saturated thickness, } \\
2009\end{array}$} & \multicolumn{8}{|c|}{ Number of wells measured, by water year } \\
\hline & & & \multicolumn{8}{|c|}{ Water-level comparison periods } \\
\hline & & & \multicolumn{2}{|c|}{1980 to 1995} & \multicolumn{2}{|c|}{1995 to 2000} & \multicolumn{2}{|c|}{2000 to 2005} & \multicolumn{2}{|c|}{2005 to 2009} \\
\hline & & & 1980 & 1995 & 1995 & 2000 & 2000 & 2005 & 2005 & 2009 \\
\hline 1980 & 238 & -- & 236 & -- & -- & -- & -- & -- & -- & -- \\
\hline 1995 & 235 & -- & -- & 12 & 3 & -- & -- & -- & -- & -- \\
\hline 1996 & 751 & -- & -- & 61 & 211 & -- & -- & -- & -- & -- \\
\hline 1997 & 547 & -- & -- & 163 & 115 & -- & -- & -- & -- & -- \\
\hline 1998 & 138 & -- & -- & -- & -- & -- & -- & -- & -- & -- \\
\hline 1999 & 24 & -- & -- & -- & -- & -- & -- & -- & -- & -- \\
\hline 2000 & 114 & -- & -- & -- & -- & 2 & 1 & -- & -- & -- \\
\hline 2001 & 269 & -- & -- & -- & -- & 171 & 122 & -- & -- & -- \\
\hline 2002 & 206 & -- & -- & -- & -- & 156 & 129 & -- & -- & -- \\
\hline 2003 & 148 & -- & -- & -- & -- & -- & -- & -- & -- & -- \\
\hline 2004 & 79 & -- & -- & -- & -- & -- & -- & -- & -- & -- \\
\hline 2005 & 73 & 6 & -- & -- & -- & -- & -- & 7 & 1 & -- \\
\hline 2006 & 306 & 198 & -- & -- & -- & -- & -- & 158 & 11 & -- \\
\hline 2007 & 102 & 23 & -- & -- & -- & -- & -- & 87 & 60 & -- \\
\hline 2008 & 67 & 19 & -- & -- & -- & -- & -- & -- & -- & -- \\
\hline 2009 & 71 & 61 & -- & -- & -- & -- & -- & -- & -- & 18 \\
\hline 2010 & 77 & -- & -- & -- & -- & -- & -- & -- & -- & 54 \\
\hline Total & 3,445 & 307 & 236 & 236 & 329 & 329 & 252 & 252 & 72 & 72 \\
\hline
\end{tabular}

Table 3. Distribution of aquifer area, area of little or no saturated thickness, and volume of saturated material, High Plains aquifer, 2009, by State and in total.

$[--$, not applicable]

\begin{tabular}{|c|c|c|c|}
\hline State & $\begin{array}{l}\text { Area underlain } \\
\text { by High Plains } \\
\text { aquifer, in } \\
\text { square miles }\end{array}$ & $\begin{array}{l}\text { Area with little } \\
\text { or no saturated } \\
\text { thickness, in } \\
\text { square miles }\end{array}$ & $\begin{array}{c}\text { Volume of } \\
\text { saturated aquifer } \\
\text { material, in } \\
\text { million acre-feet }\end{array}$ \\
\hline Colorado & 13,300 & 1,400 & 500 \\
\hline Kansas & 30,900 & 5,340 & 1,600 \\
\hline Nebraska & 64,600 & 80 & 13,200 \\
\hline New Mexico & 9,300 & 3,590 & 200 \\
\hline Oklahoma & 7,400 & 340 & 500 \\
\hline South Dakota & 4,900 & -- & 600 \\
\hline Texas & 36,300 & 30 & 2,100 \\
\hline Wyoming & 8,100 & -- & 800 \\
\hline $\begin{array}{l}\text { High Plains } \\
\text { aquifer }\end{array}$ & 175,000 & 10,800 & 19,500 \\
\hline
\end{tabular}

\footnotetext{
${ }^{1}$ Aquifer boundary from Qi (2010), which is a modification of the Weeks
} and Gutentag (1981) boundary.

${ }^{2}$ As described by Gutentag and others (1984). by multiplying the volume of saturated material in the aquifer by average-mapped specific yield (fig. 2; Gutentag and others, 1984; Cederstrand and Becker, 1998).

The specific yield of the High Plains aquifer was estimated using drillers' and geologists' descriptive logs of rocks and sediment comprising the aquifer matrix from wells and test holes generally drilled to the base of the aquifer (Gutentag and others, 1984). An area-weighted, average specific yield was calculated for each well or test hole, and specific yield was mapped for defined areas of the aquifer, for example, $0-5$ percent, 5-10 percent, and so forth. Specific yield of the High Plains aquifer ranges from near zero to about 30 percent; the average of the mapped specific yield ranges from 2.5 to 27.5 percent (fig. 2). Average area-weighted specific yield, using average-mapped specific yield and not including areas of little or no saturated thickness, by State, ranges from 8.1 percent in Wyoming to 18.5 percent in Oklahoma and is 15.1 percent for the aquifer (table 4).

The volume of water in storage in the High Plains aquifer was estimated at about 3.2 billion acre- $\mathrm{ft}$ in 1980 (Gutentag and others, 1984), about 3.0 billion acre-ft in 2000 (McGuire and other, 2003), and about 2.9 billion acre-ft in 2009 (McGuire, 2011). The volume of water in storage in 2009 in the High Plains aquifer is re-estimated in this report at about 


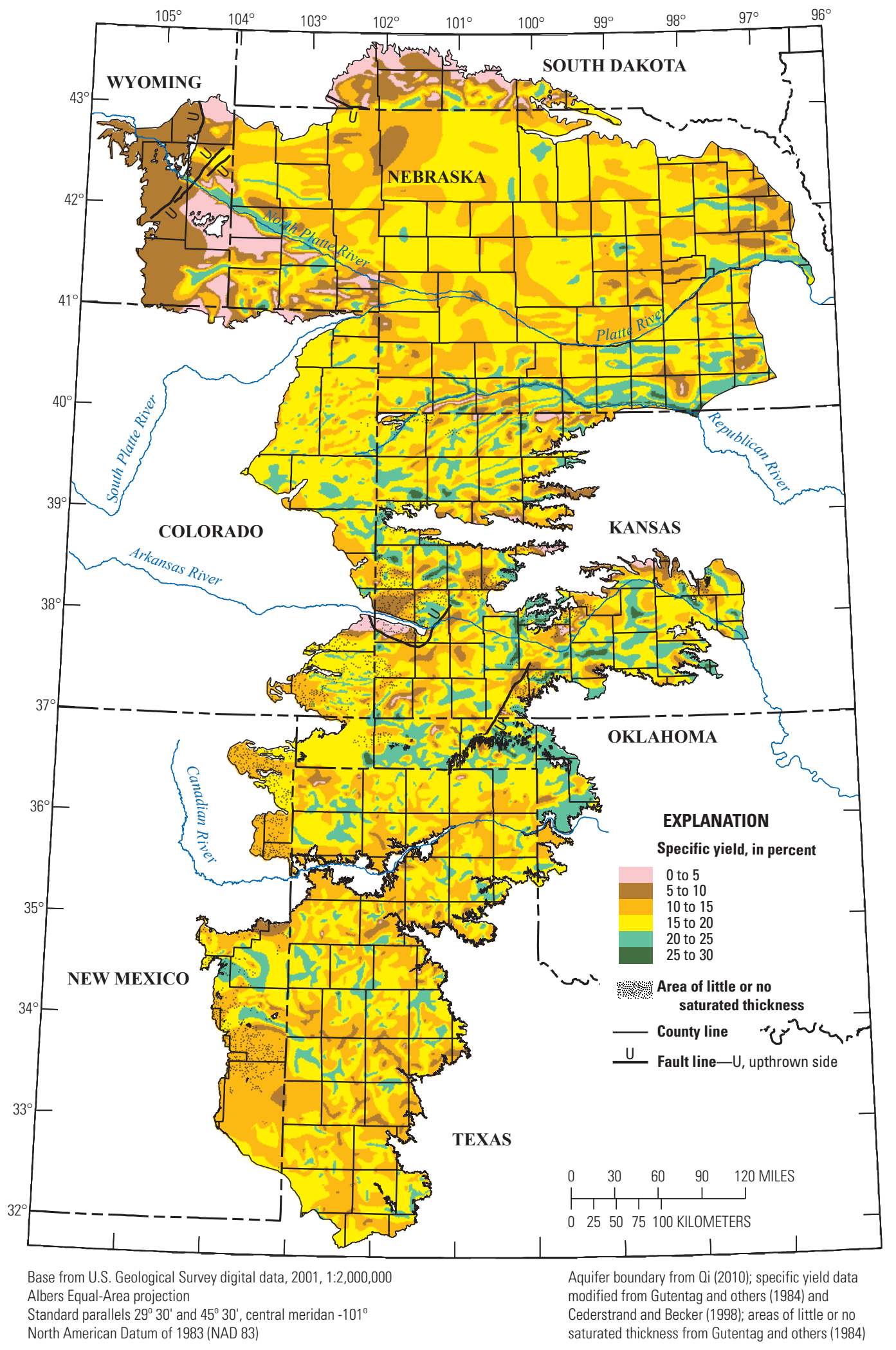

Figure 2. Specific yield of the High Plains aquifer. 
Table 4. Area-weighted, average specific yield using averagemapped specific yield generated from a contour map of specific yield ranges of the High Plains aquifer, by State and in total, with and without areas of little or no saturated thickness.

\begin{tabular}{|c|c|c|}
\hline \multirow[b]{2}{*}{ State } & \multicolumn{2}{|c|}{$\begin{array}{l}\text { Area-weighted, average specific yield, } \\
\text { in percent }{ }^{1}\end{array}$} \\
\hline & $\begin{array}{l}\text { Including areas } \\
\text { of little or no } \\
\text { saturated } \\
\text { thickness }\end{array}$ & $\begin{array}{l}\text { Not including } \\
\text { areas of little or } \\
\text { no saturated } \\
\text { thickness }^{2}\end{array}$ \\
\hline Colorado & 16.3 & 16.3 \\
\hline Kansas & 16.1 & 16.4 \\
\hline Nebraska & 15.1 & 15.1 \\
\hline New Mexico & 14.3 & 14.8 \\
\hline Oklahoma & 18.4 & 18.5 \\
\hline South Dakota & 9.1 & 9.1 \\
\hline Texas & 15.3 & 15.3 \\
\hline Wyoming & 8.1 & 8.1 \\
\hline High Plains aquifer & 15.0 & 15.1 \\
\hline \multicolumn{3}{|c|}{$\begin{array}{l}{ }^{1} \text { Modified from Gutentag and others (1984); Cederstrand and Becker } \\
\text { (1998). }\end{array}$} \\
\hline
\end{tabular}

3.0 billion acre-ft (table 5). Different methods were used to calculate water in storage for 1980, 2000, and 2009 in previous reports (Gutentag and others, 1984; McGuire and others, 2003; and McGuire, 2011) and in this report. Previously reported values for water in storage in 2000 (McGuire and others, 2003) were calculated using the average value associated with the mapped polygons and the average area-weighted specific yield of the aquifer (15.1 percent). Previously reported values for water in storage in 2009 (McGuire, 2011) were calculated using the average value associated with the mapped polygons of saturated thickness in 2000, Thiessen polygons (Thiessen, 1911) of water-level changes from 2000 to 2009, and the average area-weighted specific yield (15.1 percent) of the aquifer. In this report, water in storage for 2009 was calculated using a raster file of saturated thickness for 2009, and a raster file of average-mapped specific yield that was generated from a contour map of specific yield ranges (Gutentag and others, 1984; Cederstrand and Becker, 1998).

The volume of water in storage in 2009 by State, as calculated in this report, ranges from about 30 million acre- $\mathrm{ft}$ in New Mexico to 2,040 million acre-ft in Nebraska (table 5). The volume of water in storage in 2009 by county is listed in appendix 1 . The volume of water in storage by county ranges from near zero in several counties underlain by the aquifer to 287 million acre-ft in Cherry County, Nebraska.

Table 5. Distribution of water in storage in the High Plains aquifer, 1980, 2000, and 2009, by State and in total, as calculated in this report and in previous reports.

\begin{tabular}{|c|c|c|c|c|}
\hline \multirow{4}{*}{ State } & \multicolumn{4}{|c|}{ Water in storage, in million acre-feet } \\
\hline & \multirow{2}{*}{$\begin{array}{c}\text { Calculated in this report } \\
\text { Calculated using average-mapped } \\
\text { specific yield generated from } \\
\text { a contour map of specific yield } \\
\text { ranges }^{1} \\
\end{array}$} & \multicolumn{3}{|c|}{ Calculated in previous reports } \\
\hline & & \multicolumn{3}{|c|}{$\begin{array}{l}\text { Calculated using area-weighted, average specific yield for the aquifer } \\
\qquad(15.1 \text { percent })^{2}\end{array}$} \\
\hline & 2009 & 21980 & ${ }^{3} 2000$ & ${ }^{4} 2009$ \\
\hline Kansas & 260 & 320 & 270 & 260 \\
\hline Nebraska & 2,040 & 2,130 & 2,000 & 1,980 \\
\hline New Mexico & 30 & 50 & 40 & 30 \\
\hline Oklahoma & 90 & 110 & 110 & 100 \\
\hline High Plains aquifer & 2,960 & 3,250 & 2,970 & 2,900 \\
\hline \multicolumn{5}{|c|}{${ }^{1}$ Gutentag and others (1984); Cederstrand and Becker (1998). } \\
\hline \multicolumn{5}{|c|}{${ }^{2}$ Gutentag and others (1984). } \\
\hline \multicolumn{5}{|c|}{${ }^{3}$ Modified from McGuire and others (2003). } \\
\hline${ }^{4}$ Modified from $\mathrm{McGl}$ & & & & \\
\hline
\end{tabular}




\section{Water-Level Changes and Changes in Water in Storage, 1980 to 1995}

The map of water-level changes in the High Plains aquifer from 1980 to 1995 (fig. 3) is based on water-level data collected from 5,783 wells (table 1). Measured water-level changes from 1980 to 1995 ranged from a rise of about $48 \mathrm{ft}$ in Nebraska to a decline of about $82 \mathrm{ft}$ in New Mexico. Areaweighted, average water-level change from 1980 to 1995 for the aquifer was a decline of $2.0 \mathrm{ft}$; the area-weighted, average water-level change from 1980 to 1995 by State ranged from a decline of $6.6 \mathrm{ft}$ in Kansas to a rise of $1.1 \mathrm{ft}$ in Nebraska (table 6). McGuire and Sharpe (1997) calculated that the areaweighted, average water-level change from 1980 to 1995 for the aquifer was a decline of $2.4 \mathrm{ft}$ (table 6). The difference in the values for the area-weighted, average water-level change from 1980 to 1995 in McGuire and Sharpe (1997) and in this report can be attributed to a difference in calculation methods. McGuire and Sharpe (1997) used Thiessen polygons (Thiessen, 1911) to calculate area-weighted, average water-level changes; in this report, an interpolated raster file of water-level changes was used in the calculation.

McGuire and Sharpe (1997) calculated that water in storage from 1980 to 1995 decreased by 40.2 million acre-ft (table 7). The change in water in storage in the High Plains aquifer from 1980 to 1995 calculated in this report was a decrease of about 36.0 million acre-ft (table 7). The difference in these values (4.2 million acre-ft or about 10 percent less depletion in this report) was caused by a difference in calculation methods. McGuire and Sharpe (1997) used Thiessen polygons (Thiessen, 1911) and the average area-weighted specific yield for the aquifer (15.1 percent) in their calculation. In this report, changes in water in storage were calculated using a raster file of water-level changes and a raster file of average-mapped specific yield generated from a contour map of specific yield ranges (Gutentag and others, 1984; Cederstrand and Becker, 1998).

\section{Water-Level Changes and Changes in Water in Storage, 1995 to 2000}

The map of water-level changes in the High Plains aquifer from 1995 to 2000 (fig. 4) is based on water-level data collected from 5,971 wells (table 1). Measured water-level changes from 1995 to 2000 ranged from a rise of about $26 \mathrm{ft}$ in Texas to a decline of about $60 \mathrm{ft}$ in Texas. The area-weighted, average water-level change from 1995 to 2000 for the aquifer was a decline of $1.3 \mathrm{ft}$; the area-weighted, average water-level change from 1995 to 2000 by State ranged from a decline of $4.7 \mathrm{ft}$ in Texas to a rise of $0.8 \mathrm{ft}$ in South Dakota (table 6). Previously reported area-weighted, average water-level change from 1995 to $2000 \mathrm{for}$ the aquifer was a decline of $1.1 \mathrm{ft}$ (McGuire and others, 1997; McGuire and Fischer, 1999a and 1999b; McGuire, 2001 and 2003; table 6). The difference in these values reflects a difference in calculation methods. Previously reported area-weighted, average water-level change from 1995 to 2000 (McGuire and others, 1997; McGuire and Fischer, 1999a and 1999b; McGuire, 2001 and 2003) was calculated using Thiessen polygons (Thiessen, 1911); in this report, an interpolated raster file of water-level changes was used in the calculation.

Previously reported change in water in storage for the High Plains aquifer from 1995 to 2000 was a decline of 17.6 million acre-ft (McGuire, 2011). The change in water in storage for the High Plains aquifer from 1995 to 2000 calculated in this report was a decline of 23.5 million acre-ft (table 7). The difference in these values (5.9 million acre- $\mathrm{ft}$ or about 33 percent more depletion in this report) is caused by a difference in calculation methods. Previously reported changes in water in storage from 1995 to 2000 were calculated using Thiessen polygons (Thiessen, 1911) and average area-weighted specific yield for the aquifer (15.1 percent). In this report, changes in water in storage were calculated using a raster file of water-level changes and a raster file of average-mapped specific yield generated from a contour map of specific yield ranges (Gutentag and others, 1984; Cederstrand and Becker, 1998).

\section{Water-Level Changes and Changes in Water in Storage, 2000 to 2005}

The map of water-level changes in the High Plains aquifer from 2000 to 2005 (fig. 5) is based on water-level data collected from 7,248 wells (table 1). Measured water-level changes from 2000 to 2005 ranged from a rise of about $17 \mathrm{ft}$ in Oklahoma to a decline of about $44 \mathrm{ft}$ in Texas. The areaweighted, average water-level change from 2000 to 2005 for the aquifer was a decline of $2.8 \mathrm{ft}$; the area-weighted, average water-level change from 2000 to 2005 by State ranged from a decline of $4.3 \mathrm{ft}$ in Kansas to a decline of $0.5 \mathrm{ft}$ in Oklahoma (table 6). The previously reported area-weighted, average water-level change from 2000 to 2005 for the aquifer was a decline of $3.4 \mathrm{ft}$ (McGuire, 2003, 2004a; 2004b; 2007; table 6). The difference in these values is caused by differences in calculation methods. Previously reported areaweighted, average water-level changes from 2000 to 2005 (McGuire, 2003, 2004a; 2004b; 2007) was calculated using Thiessen polygons (Thiessen, 1911); this report uses an interpolated raster file of water-level changes for that calculation.

The previously reported change in water in storage from 2000 to 2005 was a decline of 55.4 million acre-ft (McGuire, 2011). The change in water in storage in the High Plains aquifer from 2000 to 2005 calculated in this report was a decline of 46.7 million acre-ft (table 7). The difference in these values (8.7 million acre- $\mathrm{ft}$ or about 16 percent less depletion in this report) is caused by differences in calculation methods. The previously reported changes in water in storage from 2000 


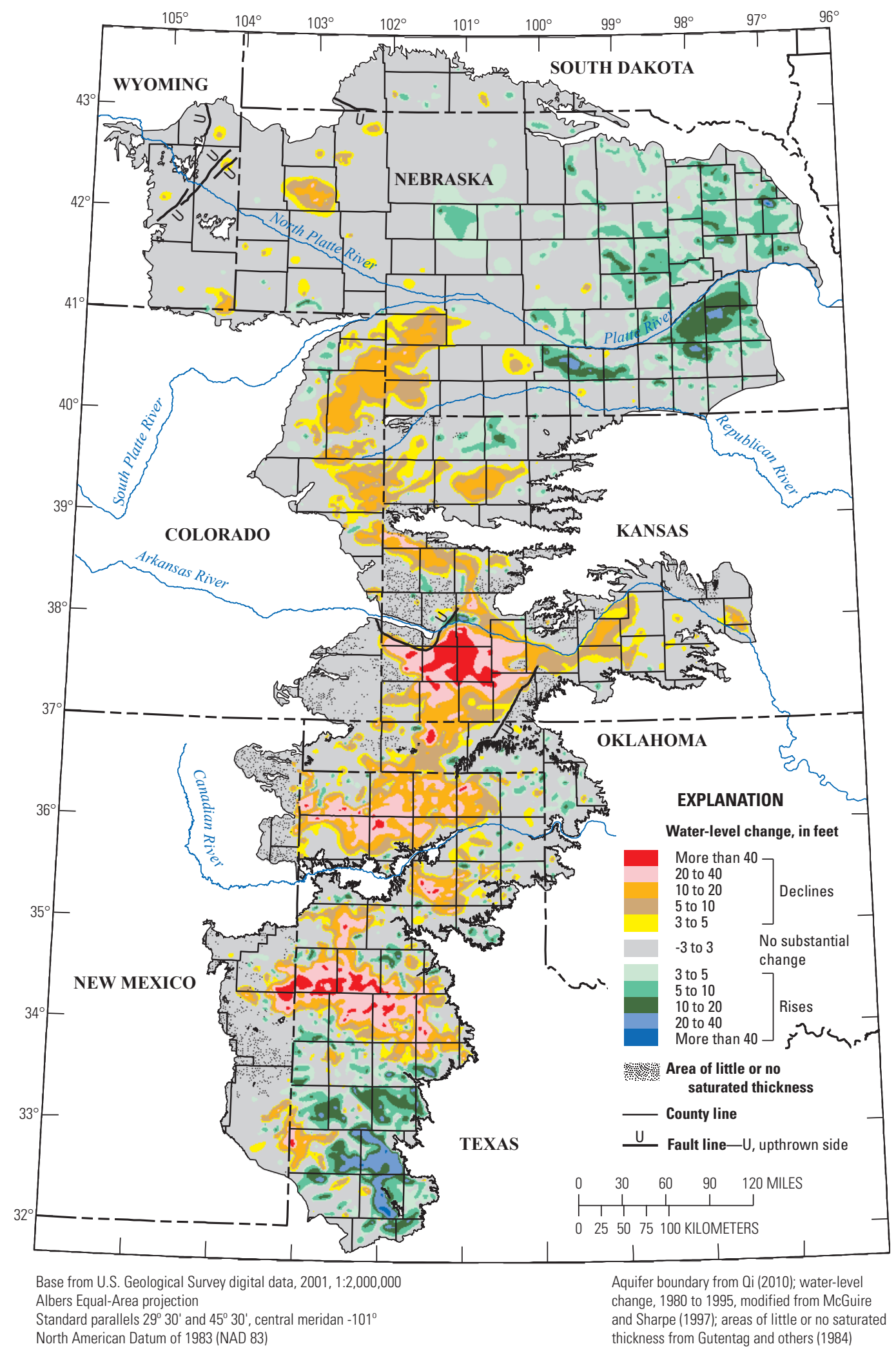

Figure 3. Water-level changes in the High Plains aquifer, 1980 to 1995. 
Table 6. Distribution of area-weighted, average water-level changes in the High Plains aquifer, 1980 to 1995, 1995 to 2000, 2000 to 2005, and 2005 to 2009, by State and in total, as calculated in this report and in previous reports.

\begin{tabular}{|c|c|c|c|c|c|c|c|c|}
\hline \multirow{3}{*}{ State } & \multicolumn{4}{|c|}{ Calculated in this report } & \multicolumn{4}{|c|}{ Calculated in previous reports } \\
\hline & \multicolumn{4}{|c|}{$\begin{array}{l}\text { Area-weighted, average water-level changes, in feet, } \\
\text { calculated using an interpolated raster }\end{array}$} & \multicolumn{4}{|c|}{$\begin{array}{l}\text { Area-weighted, average water-level changes, in feet } \\
\text { calculated using Theissen polygons }\end{array}$} \\
\hline & $\begin{array}{c}1980 \text { to } \\
1995\end{array}$ & $\begin{array}{c}1995 \text { to } \\
2000\end{array}$ & $\begin{array}{l}2000 \text { to } \\
2005\end{array}$ & $\begin{array}{c}2005 \text { to } \\
2009\end{array}$ & $\begin{array}{c}\text { '1980 to } \\
1995\end{array}$ & $\begin{array}{c}21995 \text { to } \\
2000\end{array}$ & $\begin{array}{c}{ }^{3} 2000 \text { to } \\
2005\end{array}$ & $\begin{array}{c}{ }^{4} 2005 \text { to } \\
2009\end{array}$ \\
\hline Colorado & -3.0 & -1.0 & -2.9 & -2.2 & -4.2 & -0.6 & -3.8 & -3.9 \\
\hline Kansas & -6.6 & -1.6 & -4.3 & -2.4 & -7.5 & -0.9 & -4.8 & -2.2 \\
\hline Nebraska & 1.1 & 0.3 & -2.9 & 0.5 & 1.8 & 0.8 & -3.8 & 0.5 \\
\hline New Mexico & -3.3 & -1.9 & -1.7 & -0.9 & -3.1 & -3.8 & -3.1 & -3.2 \\
\hline Oklahoma & -2.1 & -1.6 & -0.5 & -1.2 & -2.8 & -1.1 & -0.7 & -2.2 \\
\hline South Dakota & 0.1 & 0.8 & -0.7 & -0.3 & -0.6 & 2.5 & -1.2 & 0.1 \\
\hline Texas & -4.3 & -4.7 & -2.7 & -2.6 & -4.8 & -4.9 & -3.2 & -2.5 \\
\hline Wyoming & -0.2 & 0.1 & -0.7 & -0.4 & -3.4 & 0 & -2.2 & -1.2 \\
\hline High Plains aquifer & -2.0 & -1.3 & -2.8 & -1.0 & -2.4 & -1.1 & -3.4 & -1.4 \\
\hline
\end{tabular}

Table 7. Distribution of changes in water in storage in the High Plains aquifer, 1980 to 1995, 1995 to 2000, 2000 to 2005, and 2005 to 2009, by State and in total, as calculated in this report and in previous reports.

$[--$, not calculated]

\begin{tabular}{|c|c|c|c|c|c|c|c|c|}
\hline \multirow{3}{*}{ State } & \multicolumn{4}{|c|}{ Calculated in this report } & \multicolumn{4}{|c|}{ Calculated in previous reports } \\
\hline & \multicolumn{4}{|c|}{$\begin{array}{c}\text { Changes in water in storage, in million acre-feet, } \\
\text { calculated using interpolated water-level change } \\
\text { raster and raster of average-mapped specific yield } \\
\text { generated from a contour map of specific yield } \\
\text { ranges }^{1}\end{array}$} & \multicolumn{4}{|c|}{$\begin{array}{l}\text { Changes in water in storage, in million acre-feet, } \\
\text { calculated using Theissen polygons of water-level-change } \\
\text { results and area-weighted, average specific yield of the } \\
\text { aquifer (15.1 percent) }\end{array}$} \\
\hline & $\begin{array}{c}1980 \text { to } \\
1995\end{array}$ & $\begin{array}{c}1995 \text { to } \\
2000\end{array}$ & $\begin{array}{c}2000 \text { to } \\
2005\end{array}$ & $\begin{array}{c}2005 \text { to } \\
2009\end{array}$ & $\begin{array}{c}31980 \text { to } \\
1995\end{array}$ & $\begin{array}{c}{ }^{4} 1995 \text { to } \\
2000\end{array}$ & $\begin{array}{c}{ }^{4} 2000 \text { to } \\
2005\end{array}$ & $\begin{array}{c}{ }^{4} 2005 \text { to } \\
2009\end{array}$ \\
\hline Colorado & -4.0 & -1.4 & -3.7 & -2.9 & -6.0 & -- & -- & -4.4 \\
\hline Kansas & -17.4 & -4.2 & -11.6 & -6.5 & -22.0 & -- & -- & -5.6 \\
\hline Nebraska & 7.4 & 2.4 & -18.8 & 3.0 & 10.9 & -- & -- & 2.8 \\
\hline New Mexico & -2.0 & -1.1 & -1.0 & -0.5 & -2.8 & -- & -- & -1.8 \\
\hline Oklahoma & -1.8 & -1.3 & -0.4 & -1.0 & -2.0 & -- & -- & -1.5 \\
\hline High Plains aquifer & -36.0 & -23.5 & -46.7 & -18.3 & -40.2 & -17.6 & -55.4 & -20.4 \\
\hline
\end{tabular}

${ }^{1}$ Modified from Gutentag and others (1984); Cederstand and Becker (1998).

${ }^{2}$ Gutentag and others (1984).

${ }^{3}$ Modified from McGuire and Sharpe (1997).

${ }^{4}$ Modified from McGuire (2011). 


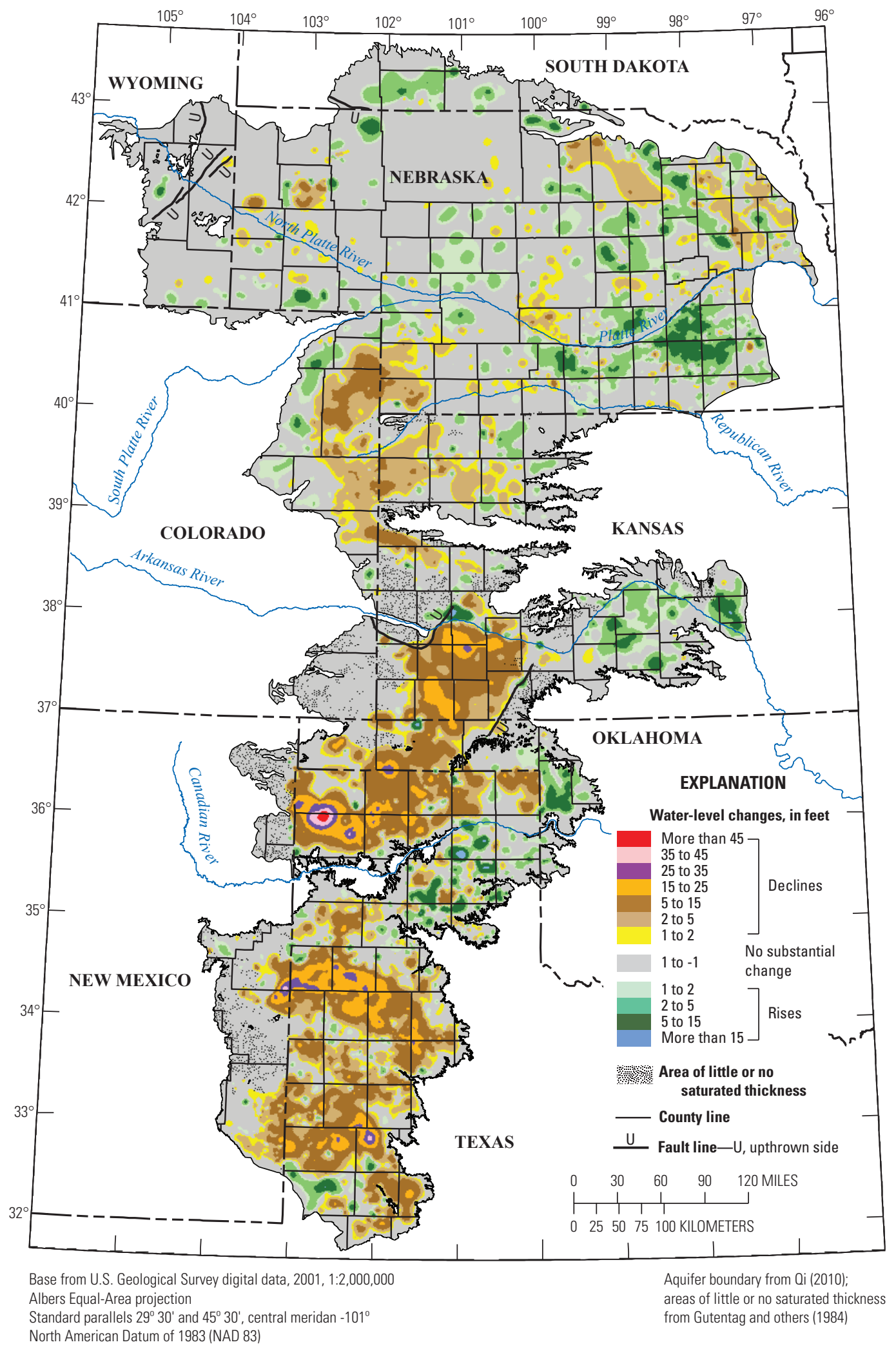

Figure 4. Water-level changes in the High Plains aquifer, 1995 to 2000. 


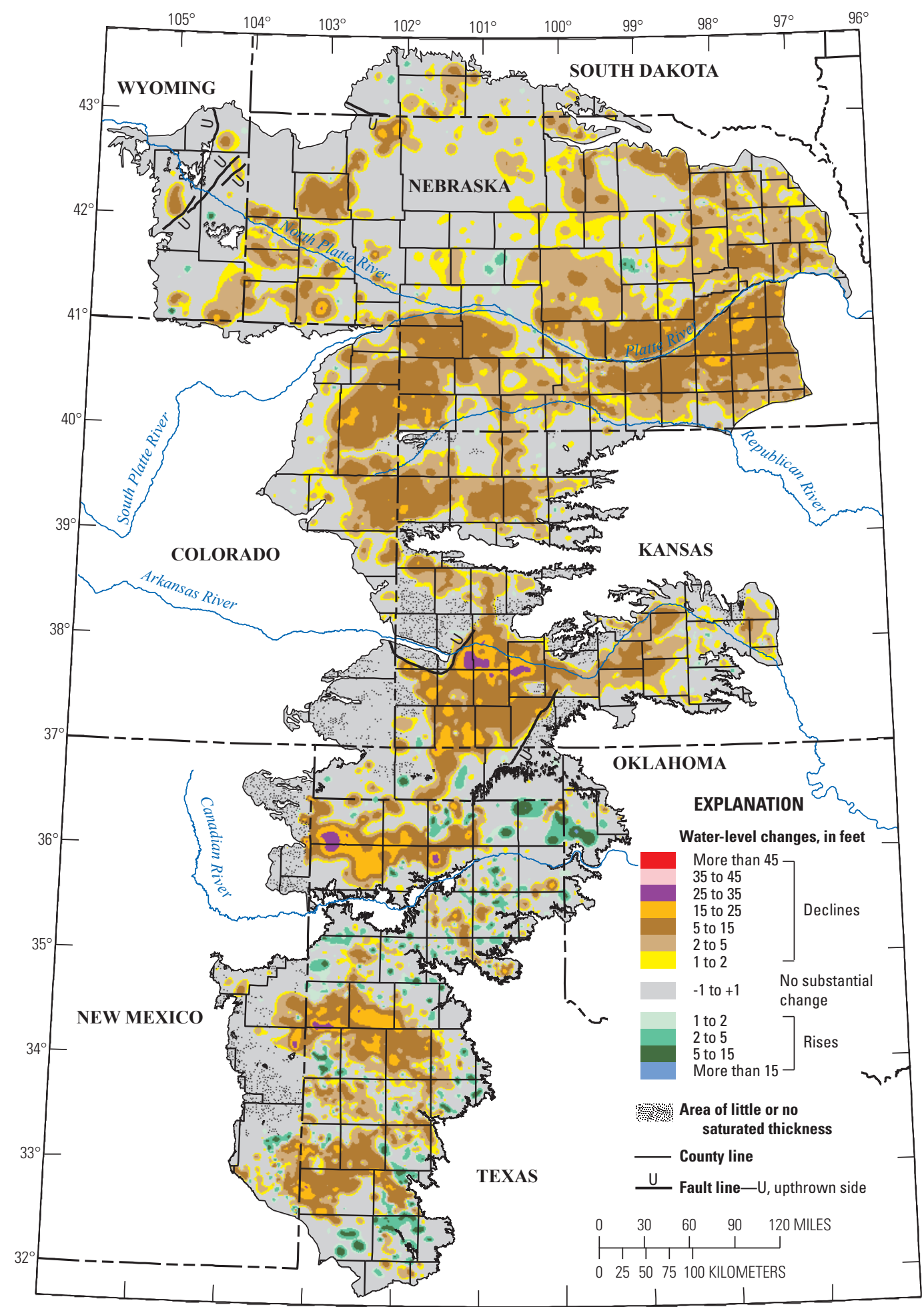

Base from U.S. Geological Survey digital data, 2001, 1:2,000,000 Albers Equal-Area projection

Standard parallels $29^{\circ} 30^{\prime}$ and $45^{\circ} 30^{\prime}$, central meridan $-101^{\circ}$ North American Datum of 1983 (NAD 83)

Aquifer boundary from Qi (2010); areas of little or no saturated thickness from Gutentag and others (1984)

Figure 5. Water-level changes in the High Plains aquifer, 2000 to 2005. 
to 2005 were calculated using Thiessen polygons (Thiessen, 1911) and the average area-weighted specific yield for the aquifer (15.1 percent). In this report, changes in water in storage were calculated using a raster file of water-level changes and a raster file of average-mapped specific yield generated from a contour map of specific yield ranges (Gutentag and others, 1984; Cederstrand and Becker, 1998).

\section{Water-Level Changes and Changes in Water in Storage, 2005 to 2009}

The map of water-level changes in the High Plains aquifer from 2005 to 2009 (fig. 6) is based on water-level data collected from 7,429 wells (table 1). Measured water-level changes from 2005 to 2009 ranged from a rise of about $32 \mathrm{ft}$ in Oklahoma to a decline of about $45 \mathrm{ft}$ in Texas. The areaweighted, average water-level change from 2005 to 2009 for the aquifer was a decline of $1.0 \mathrm{ft}$; the area-weighted, average water-level change from 2005 to 2009 by State ranged from a decline of $2.6 \mathrm{ft}$ in Texas to a rise of $0.5 \mathrm{ft}$ in Nebraska (table 6). The previously reported area-weighted, average water-level change from 2005 to 2009 for the aquifer was a decline of $1.4 \mathrm{ft}$ (McGuire, 2009 and 2011; table 6). The difference in these values is caused by differences in calculation methods. The previously reported area-weighted, average water-level change from 2005 to 2009 (McGuire, 2009 and 2011) was calculated using Thiessen polygons (Thiessen, 1911); in this report, an interpolated raster file of water-level changes was used for that calculation.

The previously reported change in water in storage from 2005 to 2009 was a decline of 20.4 million acre-ft (McGuire, 2009 and 2011). The change in water in storage in the High Plains aquifer from 2005 to 2009 as calculated in this report was a decline of 18.3 million acre-ft (table 7). The difference in these values ( 2.1 million acre-ft or about 10 percent less depletion in this report) was caused by differences in calculation methods. The previously reported changes in water in storage from 2005 to 2009 were calculated using Thiessen polygons (Thiessen, 1911) and the aquifer average area-weighted specific yield (15.1 percent). In this report, changes in water in storage were calculated by using a raster file of water-level changes and a raster file of average-mapped specific yield generated from a contour map of specific yield ranges (Gutentag and others, 1984; Cederstrand and Becker, 1998). 


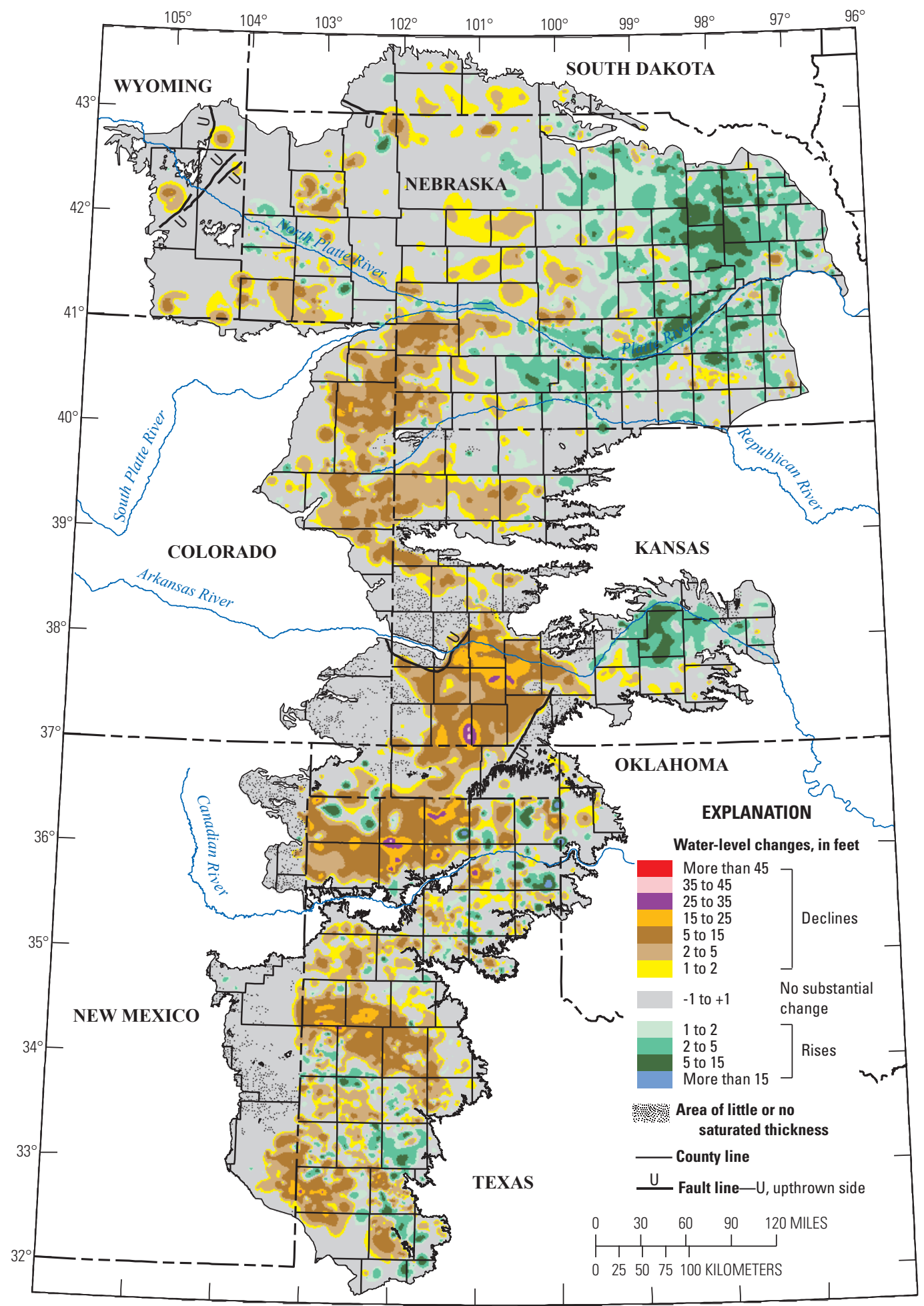

Base from U.S. Geological Survey digital data, 2001, 1:2,000,000 Albers Equal-Area projection

Standard parallels $29^{\circ} 30^{\prime}$ and $45^{\circ} 30^{\prime}$, central meridan $-101^{\circ}$ North American Datum of 1983 (NAD 83)

Aquifer boundary from Qi (2010); areas of little or no saturated thickness from Gutentag and others (1984)

Figure 6. Water-level changes in the High Plains aquifer, 2005 to 2009. 


\section{Summary}

The High Plains aquifer underlies about 112 million acres [about 175,000 square miles $\left(\mathrm{mi}^{2}\right)$ ] in parts of eight StatesColorado, Kansas, Nebraska, New Mexico, Oklahoma, South Dakota, Texas, and Wyoming. Water levels declined in parts of the High Plains aquifer soon after the onset of substantial irrigation with groundwater (about 1950). This report describes the volume of saturated material and drainable water in storage in the High Plains aquifer in 2009; water-level changes in the High Plains aquifer from 1980 to 1995,1995 to 2000 , 2000 to 2005, and 2005 to 2009; and change in the volume of drainable water in storage in the aquifer from 1980 to 1995 , 1995 to 2000, 2000 to 2005, and 2005 to 2009 using raster files with a cell size of about 62 acres. Water levels used in this report generally were measured in winter or early spring. At this time, irrigation wells typically were not pumping, and water levels generally had recovered from pumping during the previous irrigation season.

The volume of saturated material in the aquifer in 2009 was estimated from a saturated thickness map of the aquifer for 2009. The volume of saturated material in the aquifer in 2009 by State ranged from 200 million acre-ft in New Mexico to 13,200 million acre-ft in Nebraska. Water in storage in the High Plains aquifer in 2009 was calculated by multiplying the volume of saturated material in the aquifer by the average specific yield in defined areas of specific yield ranges. Averagemapped specific yield ranges from 2.5 to 27.5 percent. The average area-weighted specific yield using average-mapped specific yield by State ranges from 8.1 percent in Wyoming to 18.5 percent in Oklahoma and is 15.1 percent for the aquifer, not including the areas of little or no saturated thickness. The volume of water in storage in 2009 in the High Plains aquifer was estimated at about 3.0 billion acre-ft in this report.

The map of water-level changes in the High Plains aquifer from 1980 to 1995 was based on water levels from 5,783 wells. Area-weighted, average water-level change from 1980 to 1995 for the aquifer was a decline of $2.0 \mathrm{ft}$; the areaweighted, average water-level change from 1980 to 1995 by State ranged from a decline of $6.6 \mathrm{ft}$ in Kansas to a rise of $1.1 \mathrm{ft}$ in Nebraska. The change in water in storage in the High Plains aquifer from 1980 to 1995 calculated in this report was a decline of about 36.0 million acre-ft.

Water-level changes in the High Plains aquifer from 1995 to 2000 in this report were based on water levels measured in 5,971 wells. The area-weighted, average water-level change from 1995 to 2000 for the aquifer was a decline of $1.3 \mathrm{ft}$; the area-weighted, average water-level change from 1995 to 2000 by State ranged from a decline of $4.7 \mathrm{ft}$ in Texas to a rise of $0.8 \mathrm{ft}$ in South Dakota. The change in water in storage in the High Plains aquifer from 1995 to 2000 calculated in this report was a decline of 23.5 million acre-ft.

Water-level changes in the High Plains aquifer from 2000 to 2005 were based on water levels measured in 7,248 wells. The area-weighted, average water-level change from 2000 to
2005 for the aquifer was a decline of $2.8 \mathrm{ft}$; the area-weighted, average water-level change from 2000 to 2005 by State ranged from a decline of $4.3 \mathrm{ft}$ in Kansas to a decline of $0.5 \mathrm{ft}$ in Oklahoma. The change in water in storage in the High Plains aquifer from 2000 to 2005 calculated in this report was a decline of 46.7 million acre-ft.

Water-level changes in the High Plains aquifer from 2005 to 2009 were based on water levels measured in 7,429 wells. The area-weighted, average water-level change from 2005 to 2009 for the aquifer was a decline of $1.0 \mathrm{ft}$; the area-weighted, average water-level change from 2005 to 2009 by State ranged from a decline of $2.6 \mathrm{ft}$ in Texas to a rise of $0.5 \mathrm{ft}$ in Nebraska. The change in water in storage in the High Plains aquifer from 2005 to 2009 calculated in this report was a decline of 18.3 million acre-ft.

\section{References Cited}

Alley, W.M., Reilly, T.E., and Franke, O.L., 1999, Sustainability of ground-water resources: U.S. Geological Survey Circular 1186, 79 p. (Also available at http://pubs.usgs.gov/ circ/circ1186/.)

Borman, R.G., and Meredith, T.S., 1983, Geology, altitude, and depth of the bedrock surface beneath the Ogallala Formation in the northern High Plains of Colorado: U.S. Geological Survey Hydrologic Atlas 669, 1 sheet, scale 1:500,000. (Also available at http://pubs.er.usgs.gov/djvu/ HA/ha_669_plt.djvu.)

Borman, R.G., Meredith, T.S., and Bryn, S.M., 1984, Geology, altitude, and depth of the bedrock surface; altitude of the water table in 1980; and saturated thickness of the Ogallala aquifer in 1980 in the southern High Plains of Colorado: U.S. Geological Survey Hydrologic Atlas 673, 1 sheet, scale 1:500,000.

Cederstrand, J.R., and Becker, M.F., 1998, Digital map of specific yield for High Plains aquifer in parts of Colorado, Kansas, Nebraska, New Mexico, Oklahoma, South Dakota, Texas, and Wyoming: U.S. Geological Survey Open-File Report 98-414, accessed August 2011, at http://water.usgs. gov/GIS/metadata/usgswrd/XML/ofr98-414.xml.

Cunningham, W.L., and Schalk, C.W., comps., 2011, Groundwater technical procedures of the U.S. Geological Survey: U.S. Geological Survey Techniques and Methods 1-A1, 151 p. (Available only at http://pubs.usgs.gov/tm/lal/.)

Environmental Systems Research Institute, 1992, Understanding GIS - the Arc/Info method: Redlands, Calif., Environmental Systems Research Institute, 450 p.

Environmental Systems Research Institute, variously dated, ArcDoc version 9.3: Redlands, Calif., Environmental Systems Research Institute instructions provided with software. 
Gutentag, E.D., Heimes, F.J., Krothe, N.C., Luckey, R.R., and Weeks, J.B., 1984, Geohydrology of the High Plains aquifer in parts of Colorado, Kansas, Nebraska, New Mexico, Oklahoma, South Dakota, Texas, and Wyoming: U.S. Geological Survey Professional Paper 1400-B, 63 p. (Also available at http://pubs.er.usgs.gov/publication/pp1400B.)

Hart, D.L., and McAda, D.P., 1985, Geohydrology of the High Plains aquifer in southeastern New Mexico: U.S. Geological Survey Hydrologic Atlas 679, 1 sheet, scale 1:1,000,000. (Also available at http://pubs.usgs.gov/ha/679/plate-1.pdf.)

Heimes, F.J., and Luckey, R.R., 1982, Method for estimating irrigation requirements from ground water in the High Plains in parts of Colorado, Kansas, Nebraska, New Mexico, Oklahoma, South Dakota, Texas, and Wyoming: U.S. Geological Survey Water-Resources Investigations Report 82-40, 64 p.

Houston, N.A., Garcia, C.A., and Strom, E.W., 2003, Selected hydrogeologic datasets for the Ogallala Aquifer, Texas: U.S. Geological Survey Open-File Report 2003-296, 1 CDROM.

Juracek, K.E., and Hansen, C.V., 1995, Digital maps of the extent, base, and 1991 potentiometric surface of the High Plains aquifer in Kansas: U.S. Geological Survey OpenFile Report 95-758, accessed April 2001, at http://www. kansasgis.org/catalog/index.cfm.

Kansas Geological Survey, 2010, Wizard water well levels database: Kansas Geological Survey data, accessed September 2010, at http://www.kgs.ku.edu/Magellan/WaterLevels/ index.html.

Kenny, J.F., Barber, N.L., Hutson, S.S., Linsey, K.S., Lovelace, J.K., and Maupin, M.A., 2009, Estimated use of water in the United States in 2005: U.S. Geological Survey Circular 1344, 52 p. (Also available at http://pubs.usgs.gov/ circ/1344/.)

Luckey, R.R., and Becker, M.F., 1999, Hydrogeology, water use, and simulation of flow in the High Plains aquifer in northwestern Oklahoma, southeastern Colorado, southwestern Kansas, northeastern New Mexico, and northwestern Texas: U.S. Geological Survey Water-Resources Investigations Report 99-4104, 68 p. (Also available at http://pubs. usgs.gov/wri/wri994104/pdf/wri994104.pdf.)

Luckey, R.R., Gutentag, E.D., and Weeks, J.B., 1981, Waterlevel and saturated-thickness changes, predevelopment to 1980, in the High Plains aquifer in parts of Colorado, Kansas, Nebraska, New Mexico, Oklahoma, South Dakota, Texas, and Wyoming: U.S. Geological Survey Hydrologic Investigations Atlas HA-652, 2 sheets, scale 1:2,500,000. (Also available at http://pubs.usgs.gov/ha/652/plate-1.pdf and http://pubs.usgs.gov/ha/652/plate-2.pdf.)
Maupin, M.A., and Barber, N.L., 2005, Estimated withdrawals from principal aquifers in the United States, 2000: U.S. Geological Survey Circular 1279, 46 p. (Also available at http://pubs.usgs.gov/circ/2005/1279/.)

McGuire, V.L., 2001, Water-level changes in the High Plains aquifer, 1980 to 1999: U.S. Geological Survey Fact Sheet 029-01, 2 p. (Also available at http://pubs.usgs.gov/fs/2001/ fs-029-01/.)

McGuire, V.L., 2003, Water-level changes in the High Plains aquifer, predevelopment to 2001, 1999 to 2000, and 2000 to 2001: U.S. Geological Survey Fact Sheet 078-03, 4 p. (Also available at http://pubs.usgs.gov/fs/FS078-03/.)

McGuire, V.L., 2004a, Water-level changes in the High Plains aquifer, predevelopment to 2002, 1980 to 2002, and 2001 to 2002: U.S. Geological Survey Fact Sheet 2004-3026, 6 p. (Also available at http://pubs.usgs.gov/fs/2004/3026/.)

McGuire, V.L., 2004b, Water-level changes in the High Plains aquifer, predevelopment to 2003 and 2002 to 2003: U.S. Geological Survey Fact Sheet 2004-3097, 6 p. (Also available at http://pubs.usgs.gov/fs/2004/3097/.)

McGuire, V.L., 2007, Water-level changes in the High Plains aquifer, predevelopment to 2005 and 2003 to 2005: U.S. Geological Survey Scientific Investigations Report 2006-5324, 7 p. (Also available at http://pubs.usgs.gov/ $\operatorname{sir} / 2006 / 5324 /$.)

McGuire, V.L., 2009, Water-level changes in the High Plains aquifer, predevelopment to 2007, 2005-06, and 2006-07: U.S. Geological Survey Scientific Investigations Report 2009-5019, 9 p., accessed August 2011, at http://pubs.usgs. gov/sir/2009/5019/.

McGuire, V.L., 2011, Water-level changes in the High Plains aquifer, predevelopment to 2009, 2007-08, and 2008-09, and change in water in storage, predevelopment to 2009: U.S. Geological Survey Scientific Investigations Report 2011-5089, 13 p., accessed August 2011, at http://pubs. usgs.gov/sir/2011/5089/.

McGuire, V.L., and Fischer, B.C., 1999a, Water-level changes, 1980 to 1997, and saturated thickness, 1996-97, in the High Plains aquifer: U.S. Geological Survey Fact Sheet 124-99, 4 p. (Also available at http://ne.water.usgs.gov/ogw/hpwlms/ graphics $/ 97 f$ s.pdf.)

McGuire, V.L., and Fischer, B.C., 1999b, Water-level changes in High Plains aquifer, 1980-98: U.S. Geological Survey data, accessed August 2011, at http://ne.water.usgs.gov/ogw/ hpwlms/hpfs98.html. 
McGuire, V.L., Johnson, M.R., Schieffer, R.L., Stanton, J.S., Sebree, S.K., and Verstraeten, I.M., 2003, Water in storage and approaches to ground-water management, High Plains aquifer, 2000: U.S. Geological Survey Circular 1243, 51 p. (Also available at http://pubs.usgs.gov/circ/2003/circ1243/.)

McGuire, V.L., Stanton, C.P., and Fischer, B.C., 1997, Waterlevel changes in High Plains aquifer, 1980-96: U.S. Geological Survey data, accessed August 2011, at http://ne.water. usgs.gov/ogw/hpwlms/hpfs96.html.

McGuire, V.L., and Sharpe, J.B., 1997, Water-level changes in High Plains aquifer-Predevelopment to 1995: U.S. Geological Survey Water-Resources Investigations Report 97-4081, 2 sheets, scale 1:2,500,000. (Also available at http://pubs.er.usgs.gov/djvu/WRI/wrir_97_4081_plt.djvu.)

Qi, S.L., 2010, Digital map of aquifer boundary for the High Plains aquifer in parts of Colorado, Kansas, Nebraska, New Mexico, Oklahoma, South Dakota, Texas, and Wyoming: U.S. Geological Survey Data Series 543, accessed April 2011, at http://pubs.usgs.gov/ds/543/.

Qi, S.L., Konduris, Alexandria, Litke, David W., and Dupree, Jean, 2002, Classification of irrigated land using satellite imagery, the High Plains aquifer, nominal date 1992: U.S. Geological Survey Water-Resources Investigations Report 02-4236, 35 p. (Also available at http://pubs.usgs.gov/wri/ wrir02-4236/pdf/wri02-4236.pdf.)

Taylor, C.J., and Alley, W.M., 2001, Ground-water-level monitoring and the importance of long-term water-level data: U.S. Geological Survey Circular 1217, 68 p. (Also available at http://pubs.usgs.gov/circ/circ1217/.)

Texas Water Development Board, 2010, Groundwater database: Texas Water Development Board data, accessed December 2010, at http://www.twdb.state.tx.us/ groundwater/data/gwdbrpt.asp.
Thelin, G.P., and Heimes, F.J., 1987, Mapping irrigated cropland from Landsat data for determination of water use from the High Plains aquifer in parts of Colorado, Kansas, Nebraska, New Mexico, Oklahoma, South Dakota, Texas, and Wyoming: U.S. Geological Survey Professional Paper 1400-C, 38 p. (Also available at http://pubs.usgs.gov/ pp/1400c/report.pdf.)

Thiessen, A.H., 1911, Precipitation averages for large areas: Monthly Weather Review, v. 39, p. 1,082-1,084.

U.S. Department of Agriculture, 1999, 1997 Census of agriculture, volume 1, geographic area series, part 51, United States: National Agricultural Statistics Service AC97-CDVOL1-1B, CD-ROM.

U.S. Department of Agriculture, 2004, 2002 Census of agriculture, County level data: National Agriculture Statistics Service data, v. 1, chap. 2, accessed July 2006, at http:// www.agcensus.usda.gov/Publications/2002/index.asp.

U.S. Geological Survey, 2008, Water use in the United States: U.S. Geological Survey groundwater-use data by county for 1985, 1990, 1995, 2000 and 2005, accessed December 2008, at http://water.usgs.gov/watuse/.

U.S. Geological Survey, 2011, National Water Information System: U.S. Geological Survey data, available at http:// waterdata.usgs.gov/nwis/gw.

U.S. Geological Survey, 2012, High Plains Water-Level Monitoring Study web page, U.S. Geological Survey data, available at http://ne.water.usgs.gov/ogw/hpwlms/data.html.

Weeks, J.B., and Gutentag, E.D., 1981, Bedrock geology, altitude of base, and 1980 saturated thickness of the High Plains aquifer in parts of Colorado, Kansas, Nebraska, New Mexico, Oklahoma, South Dakota, Texas, and Wyoming: U.S. Geological Survey Hydrologic Investigations Atlas HA-648, 2 sheets, scale 1:2,500,000. (Also available at http://pubs.er.usgs.gov/usgspubs/ha/ha648.) 

Appendix 1 
Table 1-1. Area-weighted, average water-level changes and changes in water in storage in the High Plains aquifer, 1980 to 1995, 1995 to 2000, 2000 to 2005, and 2005 to 2009, and water in storage in the High Plains aquifer, 2009, by county, within State.

[FIPS, Federal Information Processing Standard; ft, feet; acre-ft, acre-feet]

\begin{tabular}{|c|c|c|c|c|c|c|c|c|c|c|}
\hline \multirow{2}{*}{ County } & \multirow{2}{*}{$\begin{array}{l}\text { FIPS } \\
\text { state } \\
\text { and } \\
\text { county } \\
\text { code }\end{array}$} & \multicolumn{4}{|c|}{$\begin{array}{l}\text { Area-weighted, average water-level change, } \\
\text { in } \mathrm{ft}\end{array}$} & \multicolumn{4}{|c|}{$\begin{array}{l}\text { Changes in water in storage, } \\
\text { in million acre-ft }\end{array}$} & \multirow{2}{*}{$\begin{array}{c}\text { Water in } \\
\text { storage, } \\
2009, \\
\text { in million } \\
\text { acre-ft }\end{array}$} \\
\hline & & $\begin{array}{l}1980 \text { to } \\
1995\end{array}$ & $\begin{array}{l}1995 \text { to } \\
2000\end{array}$ & $\begin{array}{l}2000 \text { to } \\
2005\end{array}$ & $\begin{array}{l}2005 \text { to } \\
2009\end{array}$ & $\begin{array}{l}1980 \text { to } \\
1995\end{array}$ & $\begin{array}{l}1995 \text { to } \\
2000\end{array}$ & $\begin{array}{l}2000 \text { to } \\
2005\end{array}$ & $\begin{array}{c}2005 \text { to } \\
2009\end{array}$ & \\
\hline \multicolumn{11}{|c|}{ Colorado } \\
\hline Baca & 08009 & -0.1 & -0.1 & 0.0 & 0.0 & 0.0 & 0.0 & 0.0 & 0.0 & 3.8 \\
\hline Bent & 08011 & 0.0 & 0.0 & 0.0 & 0.0 & 0.0 & 0.0 & 0.0 & 0.0 & 0.0 \\
\hline Cheyenne & 08017 & -3.0 & -1.8 & -1.8 & -2.3 & -0.4 & -0.2 & -0.2 & -0.3 & 4.4 \\
\hline Elbert & 08039 & 0.0 & 0.0 & 0.0 & 0.0 & 0.0 & 0.0 & 0.0 & 0.0 & 0.0 \\
\hline Kiowa & 08061 & -0.8 & 0.7 & -0.3 & 0.0 & 0.0 & 0.0 & 0.0 & 0.0 & 0.1 \\
\hline Kit Carson & 08063 & -4.7 & -1.6 & -4.1 & -3.7 & -1.1 & -0.4 & -1.0 & -0.9 & 12.9 \\
\hline Larimer & 08069 & 0.0 & 0.0 & 0.0 & 0.0 & 0.0 & 0.0 & 0.0 & 0.0 & 0.0 \\
\hline Las Animas & 08071 & 0.0 & 0.0 & 0.0 & 0.0 & 0.0 & 0.0 & 0.0 & 0.0 & 0.1 \\
\hline Lincoln & 08073 & 0.1 & 0.7 & -0.1 & -0.3 & 0.0 & 0.1 & 0.0 & 0.0 & 2.2 \\
\hline Logan & 08075 & 1.3 & 1.2 & -1.1 & -0.5 & 0.1 & 0.1 & -0.1 & 0.0 & 1.2 \\
\hline Phillips & 08095 & -6.7 & -1.9 & -5.4 & -3.8 & -0.5 & -0.1 & -0.4 & -0.3 & 7.8 \\
\hline Prowers & 08099 & -0.5 & 0.0 & -0.1 & 0.0 & 0.0 & 0.0 & 0.0 & 0.0 & 1.0 \\
\hline Sedgwick & 08115 & -1.6 & 0.4 & -1.8 & -0.9 & -0.1 & 0.0 & -0.1 & 0.0 & 3.4 \\
\hline Washington & 08121 & -0.7 & 0.5 & -1.3 & -1.0 & -0.1 & 0.1 & -0.2 & -0.2 & 6.0 \\
\hline Weld & 08123 & -0.4 & 0.1 & -0.4 & -0.2 & 0.0 & 0.0 & 0.0 & 0.0 & 0.3 \\
\hline Yuma & 08125 & -7.5 & -3.6 & -6.9 & -4.5 & -1.8 & -0.9 & -1.7 & -1.1 & 32.7 \\
\hline \multicolumn{11}{|c|}{ Kansas } \\
\hline Barber & 20007 & 0.0 & 0.7 & -0.4 & 0.0 & 0.0 & 0.0 & 0.0 & 0.0 & 0.6 \\
\hline Barton & 20009 & 0.0 & 0.7 & -1.6 & 1.8 & 0.0 & 0.0 & -0.1 & 0.1 & 3.2 \\
\hline Cheyenne & 20023 & -1.2 & -1.4 & -2.2 & -1.4 & -0.1 & -0.1 & -0.2 & -0.1 & 6.2 \\
\hline Clark & 20025 & -0.4 & 0.0 & 0.0 & -0.4 & 0.0 & 0.0 & 0.0 & 0.0 & 0.5 \\
\hline Comanche & 20033 & 0.9 & 0.0 & 0.0 & 0.0 & 0.0 & 0.0 & 0.0 & 0.0 & 0.3 \\
\hline Decatur & 20039 & 3.3 & 1.0 & -2.0 & 0.1 & 0.3 & 0.1 & -0.2 & 0.0 & 3.9 \\
\hline Edwards & 20047 & -6.4 & 1.9 & -5.0 & 1.1 & -0.4 & 0.1 & -0.3 & 0.1 & 6.3 \\
\hline Ellis & 20051 & 0.0 & 0.0 & 0.0 & 0.0 & 0.0 & 0.0 & 0.0 & 0.0 & 0.0 \\
\hline Ellsworth & 20053 & 0.0 & 0.0 & 0.0 & 0.0 & 0.0 & 0.0 & 0.0 & 0.0 & 0.0 \\
\hline Finney & 20055 & -15.6 & -3.7 & -12.6 & -10.1 & -1.5 & -0.4 & -1.1 & -0.9 & 13.5 \\
\hline Ford & 20057 & -5.9 & -0.2 & -3.9 & -3.1 & -0.5 & 0.0 & -0.4 & -0.3 & 6.0 \\
\hline Gove & 20063 & 0.0 & 0.4 & -1.4 & -0.4 & 0.0 & 0.0 & -0.1 & 0.0 & 1.3 \\
\hline Graham & 20065 & 0.4 & 0.6 & -0.8 & 0.4 & 0.0 & 0.0 & -0.1 & 0.0 & 3.0 \\
\hline Grant & 20067 & -40.1 & -8.3 & -8.8 & -6.1 & -2.0 & -0.4 & -0.4 & -0.3 & 7.9 \\
\hline Gray & 20069 & -19.1 & -6.9 & -12.2 & -11.2 & -1.8 & -0.7 & -1.2 & -1.1 & 9.9 \\
\hline Greeley & 20071 & -5.2 & -0.9 & -2.4 & -1.6 & -0.2 & 0.0 & -0.1 & -0.1 & 1.7 \\
\hline Hamilton & 20075 & -17.5 & -1.6 & -4.7 & -3.4 & -0.2 & 0.0 & 0.0 & 0.0 & 0.7 \\
\hline Harper & 20077 & 0.0 & 0.0 & 0.0 & 0.0 & 0.0 & 0.0 & 0.0 & 0.0 & 0.1 \\
\hline Harvey & 20079 & -3.6 & 5.3 & -1.8 & 0.6 & -0.1 & 0.2 & -0.1 & 0.0 & 4.1 \\
\hline Haskell & 20081 & -42.1 & -13.3 & -13.2 & -12.3 & -2.3 & -0.7 & -0.7 & -0.7 & 11.1 \\
\hline Hodgeman & 20083 & 0.3 & 0.1 & -0.4 & 0.0 & 0.0 & 0.0 & 0.0 & 0.0 & 0.6 \\
\hline
\end{tabular}


Table 1-1. Area-weighted, average water-level changes and changes in water in storage in the High Plains aquifer, 1980 to 1995,1995 to 2000, 2000 to 2005, and 2005 to 2009, and water in storage in the High Plains aquifer, 2009, by county, within State.-Continued

[FIPS, Federal Information Processing Standard; ft, feet; acre-ft, acre-feet]

\begin{tabular}{|c|c|c|c|c|c|c|c|c|c|c|}
\hline \multirow{2}{*}{ County } & \multirow{2}{*}{$\begin{array}{l}\text { FIPS } \\
\text { state } \\
\text { and } \\
\text { county } \\
\text { code }\end{array}$} & \multicolumn{4}{|c|}{$\begin{array}{l}\text { Area-weighted, average water-level change, } \\
\text { in } \mathrm{ft}\end{array}$} & \multicolumn{4}{|c|}{$\begin{array}{l}\text { Changes in water in storage, } \\
\text { in million acre-ft }\end{array}$} & \multirow{2}{*}{$\begin{array}{c}\text { Water in } \\
\text { storage, } \\
2009, \\
\text { in million } \\
\text { acre-ft }\end{array}$} \\
\hline & & $\begin{array}{l}1980 \text { to } \\
1995\end{array}$ & $\begin{array}{l}1995 \text { to } \\
2000\end{array}$ & $\begin{array}{l}2000 \text { to } \\
2005\end{array}$ & $\begin{array}{l}2005 \text { to } \\
2009\end{array}$ & $\begin{array}{l}1980 \text { to } \\
1995\end{array}$ & $\begin{array}{l}1995 \text { to } \\
2000\end{array}$ & $\begin{array}{l}2000 \text { to } \\
2005\end{array}$ & $\begin{array}{l}2005 \text { to } \\
2009\end{array}$ & \\
\hline \multicolumn{11}{|c|}{ Kansas-Continued } \\
\hline Jewell & 20089 & 0.0 & 0.0 & -0.4 & 0.0 & 0.0 & 0.0 & 0.0 & 0.0 & 0.0 \\
\hline Kearny & 20093 & -14.0 & -3.8 & -10.1 & -7.7 & -0.7 & -0.2 & -0.5 & -0.4 & 6.2 \\
\hline Kingman & 20095 & -0.2 & 0.6 & -0.1 & -0.1 & 0.0 & 0.0 & 0.0 & 0.0 & 3.5 \\
\hline Kiowa & 20097 & -2.8 & 0.5 & -2.1 & -0.5 & -0.2 & 0.0 & -0.2 & 0.0 & 5.6 \\
\hline Lane & 20101 & -1.8 & 0.5 & -1.1 & -1.1 & -0.1 & 0.0 & 0.0 & 0.0 & 1.3 \\
\hline Logan & 20109 & -0.3 & -0.2 & -0.5 & -0.3 & 0.0 & 0.0 & 0.0 & 0.0 & 0.9 \\
\hline McPherson & 20113 & 0.0 & 1.1 & -1.4 & 0.5 & 0.0 & 0.0 & -0.1 & 0.0 & 2.2 \\
\hline Marion & 20115 & 0.0 & 0.0 & 0.0 & 0.0 & 0.0 & 0.0 & 0.0 & 0.0 & 0.0 \\
\hline Meade & 20119 & -15.5 & -4.6 & -8.5 & -7.1 & -0.9 & -0.3 & -0.5 & -0.4 & 15.1 \\
\hline Morton & 20129 & -5.5 & -2.2 & -1.8 & -1.4 & -0.3 & -0.1 & -0.1 & -0.1 & 5.1 \\
\hline Ness & 20135 & 0.0 & 0.0 & 0.0 & 0.4 & 0.0 & 0.0 & 0.0 & 0.0 & 0.1 \\
\hline Norton & 20137 & 0.0 & 0.1 & 0.0 & 0.0 & 0.0 & 0.0 & 0.0 & 0.0 & 2.6 \\
\hline Pawnee & 20145 & -2.5 & 0.8 & -2.8 & 2.3 & -0.1 & 0.0 & -0.1 & 0.1 & 2.2 \\
\hline Phillips & 20147 & 0.0 & 0.1 & -0.1 & 0.3 & 0.0 & 0.0 & 0.0 & 0.0 & 0.7 \\
\hline Pratt & 20151 & -1.6 & 2.3 & -2.5 & 0.6 & -0.2 & 0.2 & -0.2 & 0.1 & 12.5 \\
\hline Rawlins & 20153 & 1.8 & -0.2 & -1.2 & -0.1 & 0.2 & 0.0 & -0.1 & 0.0 & 6.1 \\
\hline Reno & 20155 & -0.4 & 1.3 & -0.7 & 1.5 & 0.0 & 0.1 & -0.1 & 0.2 & 10.8 \\
\hline Republic & 20157 & 0.0 & 0.0 & 0.0 & 0.0 & 0.0 & 0.0 & 0.0 & 0.0 & 0.0 \\
\hline Rice & 20159 & 0.0 & 1.1 & -0.5 & 2.0 & 0.0 & 0.0 & 0.0 & 0.1 & 2.5 \\
\hline Rooks & 20163 & 0.0 & 0.0 & 0.0 & 0.0 & 0.0 & 0.0 & 0.0 & 0.0 & 0.0 \\
\hline Rush & 20165 & 0.1 & 0.0 & 0.0 & 0.0 & 0.0 & 0.0 & 0.0 & 0.0 & 0.0 \\
\hline Scott & 20171 & -4.0 & -0.1 & -3.0 & -0.9 & -0.2 & 0.0 & -0.2 & -0.1 & 2.4 \\
\hline Sedgwick & 20173 & -1.5 & 2.5 & -0.8 & 0.2 & 0.0 & 0.1 & 0.0 & 0.0 & 2.5 \\
\hline Seward & 20175 & -14.0 & -7.5 & -8.6 & -10.0 & -1.0 & -0.5 & -0.6 & -0.7 & 21.2 \\
\hline Sheridan & 20179 & -3.9 & -0.9 & -5.3 & -1.9 & -0.4 & -0.1 & -0.5 & -0.2 & 6.0 \\
\hline Sherman & 20181 & -3.6 & -3.0 & -6.8 & -3.3 & -0.4 & -0.4 & -0.8 & -0.4 & 11.8 \\
\hline Smith & 20183 & 0.0 & 0.0 & 0.0 & 0.0 & 0.0 & 0.0 & 0.0 & 0.0 & 0.0 \\
\hline Stafford & 20185 & -1.6 & 2.1 & -3.5 & 4.9 & -0.1 & 0.2 & -0.3 & 0.5 & 12.6 \\
\hline Stanton & 20187 & -21.8 & -2.9 & -8.3 & -5.2 & -1.0 & -0.1 & -0.4 & -0.2 & 3.7 \\
\hline Stevens & 20189 & -21.6 & -12.6 & -12.5 & -12.5 & -1.6 & -0.9 & -0.9 & -1.0 & 22.0 \\
\hline Sumner & 20191 & 0.0 & 0.0 & 0.0 & 0.1 & 0.0 & 0.0 & 0.0 & 0.0 & 0.0 \\
\hline Thomas & 20193 & -4.9 & -1.7 & -4.8 & -2.2 & -0.6 & -0.2 & -0.6 & -0.3 & 9.4 \\
\hline Trego & 20195 & 0.0 & 0.0 & 0.0 & 0.0 & 0.0 & 0.0 & 0.0 & 0.0 & 0.5 \\
\hline Wallace & 20199 & -14.0 & -5.5 & -5.2 & -4.5 & -0.5 & -0.2 & -0.2 & -0.2 & 1.9 \\
\hline Wichita & 20203 & -5.7 & -1.2 & -2.4 & -2.3 & -0.4 & -0.1 & -0.1 & -0.1 & 2.2 \\
\hline \multicolumn{11}{|c|}{ Nebraska } \\
\hline Adams & 31001 & 1.7 & 1.2 & -7.0 & 0.2 & 0.1 & 0.1 & -0.5 & 0.0 & 12.5 \\
\hline Antelope & 31003 & 2.9 & 2.0 & -4.1 & 4.8 & 0.3 & 0.2 & -0.4 & 0.5 & 31.0 \\
\hline
\end{tabular}


Table 1-1. Area-weighted, average water-level changes and changes in water in storage in the High Plains aquifer, 1980 to 1995,1995 to 2000, 2000 to 2005, and 2005 to 2009, and water in storage in the High Plains aquifer, 2009, by county, within State.-Continued

[FIPS, Federal Information Processing Standard; ft, feet; acre-ft, acre-feet]

\begin{tabular}{|c|c|c|c|c|c|c|c|c|c|c|}
\hline \multirow{2}{*}{ County } & \multirow{2}{*}{$\begin{array}{l}\text { FIPS } \\
\text { state } \\
\text { and } \\
\text { county } \\
\text { code }\end{array}$} & \multicolumn{4}{|c|}{$\begin{array}{l}\text { Area-weighted, average water-level change, } \\
\text { in } \mathrm{ft}\end{array}$} & \multicolumn{4}{|c|}{$\begin{array}{l}\text { Changes in water in storage, } \\
\text { in million acre-ft }\end{array}$} & \multirow{2}{*}{$\begin{array}{c}\text { Water in } \\
\text { storage, } \\
2009, \\
\text { in million } \\
\text { acre-ft }\end{array}$} \\
\hline & & $\begin{array}{l}1980 \text { to } \\
1995\end{array}$ & $\begin{array}{l}1995 \text { to } \\
2000\end{array}$ & $\begin{array}{l}2000 \text { to } \\
2005\end{array}$ & $\begin{array}{l}2005 \text { to } \\
2009\end{array}$ & $\begin{array}{l}1980 \text { to } \\
1995\end{array}$ & $\begin{array}{l}1995 \text { to } \\
2000\end{array}$ & $\begin{array}{l}2000 \text { to } \\
2005\end{array}$ & $\begin{array}{l}2005 \text { to } \\
2009\end{array}$ & \\
\hline \multicolumn{11}{|c|}{ Nebraska-Continued } \\
\hline Arthur & 31005 & 0.0 & 0.1 & -0.7 & -0.2 & 0.0 & 0.0 & -0.1 & 0.0 & 52.1 \\
\hline Banner & 31007 & -0.3 & -0.1 & -2.6 & -0.3 & 0.0 & 0.0 & -0.1 & 0.0 & 4.6 \\
\hline Blaine & 31009 & 1.1 & 0.1 & -0.9 & 0.4 & 0.1 & 0.0 & -0.1 & 0.0 & 40.7 \\
\hline Boone & 31011 & 3.4 & 0.6 & -3.1 & 5.0 & 0.2 & 0.0 & -0.2 & 0.3 & 19.7 \\
\hline Box Butte & 31013 & -5.5 & -1.1 & -5.5 & -2.0 & -0.6 & -0.1 & -0.6 & -0.2 & 26.4 \\
\hline Boyd & 31015 & 0.0 & 0.0 & 0.0 & -0.2 & 0.0 & 0.0 & 0.0 & 0.0 & 0.0 \\
\hline Brown & 31017 & 0.0 & 0.3 & -2.0 & 0.8 & 0.0 & 0.0 & -0.3 & 0.1 & 58.9 \\
\hline Buffalo & 31019 & 1.3 & 1.5 & -8.0 & 1.7 & 0.1 & 0.1 & -0.7 & 0.1 & 23.5 \\
\hline Burt & 31021 & 2.0 & -0.8 & -1.5 & 0.8 & 0.0 & 0.0 & 0.0 & 0.0 & 0.1 \\
\hline Butler & 31023 & 3.4 & -0.4 & -8.5 & 2.6 & 0.1 & 0.0 & -0.3 & 0.1 & 5.2 \\
\hline Cedar & 31027 & 1.8 & 0.9 & -0.9 & 0.9 & 0.1 & 0.0 & 0.0 & 0.0 & 2.8 \\
\hline Chase & 31029 & -6.9 & -2.0 & -7.7 & -2.8 & -0.6 & -0.2 & -0.6 & -0.2 & 16.0 \\
\hline Cherry & 31031 & 0.4 & 0.0 & -0.5 & -0.1 & 0.2 & 0.0 & -0.3 & 0.0 & 287.2 \\
\hline Cheyenne & 31033 & 0.4 & 0.9 & -3.4 & -1.2 & 0.0 & 0.1 & -0.3 & -0.1 & 13.9 \\
\hline Clay & 31035 & 6.5 & 4.8 & -8.6 & 0.9 & 0.4 & 0.3 & -0.5 & 0.1 & 10.5 \\
\hline Colfax & 31037 & 3.9 & -1.2 & -3.8 & 0.4 & 0.1 & 0.0 & -0.1 & 0.0 & 3.9 \\
\hline Cuming & 31039 & 6.7 & -0.4 & -2.4 & 1.1 & 0.3 & 0.0 & -0.1 & 0.1 & 3.9 \\
\hline Custer & 31041 & 0.6 & -0.2 & -3.6 & -0.2 & 0.2 & 0.0 & -1.0 & -0.1 & 143.7 \\
\hline Dawes & 31045 & -0.2 & -0.1 & -0.1 & -0.1 & 0.0 & 0.0 & 0.0 & 0.0 & 11.4 \\
\hline Dawson & 31047 & 3.1 & -1.0 & -4.9 & 1.7 & 0.3 & -0.1 & -0.5 & 0.2 & 43.3 \\
\hline Deuel & 31049 & 0.3 & 0.5 & -1.6 & 0.1 & 0.0 & 0.0 & -0.1 & 0.0 & 4.2 \\
\hline Dixon & 31051 & 2.9 & -1.1 & -1.2 & 1.8 & 0.0 & 0.0 & 0.0 & 0.0 & 0.1 \\
\hline Dodge & 31053 & 3.0 & -0.1 & -2.5 & 1.1 & 0.1 & 0.0 & -0.1 & 0.1 & 4.8 \\
\hline Douglas & 31055 & 0.0 & -0.1 & 0.0 & 0.0 & 0.0 & 0.0 & 0.0 & 0.0 & 0.0 \\
\hline Dundy & 31057 & -4.5 & -2.7 & -7.5 & -3.2 & -0.4 & -0.2 & -0.7 & -0.3 & 11.4 \\
\hline Fillmore & 31059 & 2.6 & 4.4 & -6.8 & 1.4 & 0.2 & 0.3 & -0.4 & 0.1 & 12.7 \\
\hline Franklin & 31061 & 0.2 & 0.4 & -2.3 & 0.1 & 0.0 & 0.0 & -0.2 & 0.0 & 5.5 \\
\hline Frontier & 31063 & -1.1 & 0.4 & -2.6 & 2.1 & -0.1 & 0.0 & -0.3 & 0.2 & 19.4 \\
\hline Furnas & 31065 & 0.4 & -0.4 & -1.8 & 0.7 & 0.0 & 0.0 & -0.2 & 0.1 & 3.1 \\
\hline Gage & 31067 & 1.0 & 1.4 & -3.0 & 1.3 & 0.0 & 0.0 & 0.0 & 0.0 & 0.2 \\
\hline Garden & 31069 & -0.1 & 0.0 & -0.7 & -0.2 & 0.0 & 0.0 & -0.1 & 0.0 & 54.0 \\
\hline Garfield & 31071 & 3.1 & 1.3 & -0.4 & 0.5 & 0.2 & 0.1 & 0.0 & 0.0 & 32.7 \\
\hline Gosper & 31073 & 7.3 & 2.6 & -2.8 & 1.6 & 0.3 & 0.1 & -0.1 & 0.1 & 12.7 \\
\hline Grant & 31075 & 0.2 & 0.0 & -0.1 & 0.0 & 0.0 & 0.0 & 0.0 & 0.0 & 80.6 \\
\hline Greeley & 31077 & 6.1 & 1.9 & -2.0 & 1.2 & 0.3 & 0.1 & -0.1 & 0.1 & 19.5 \\
\hline Hall & 31079 & 3.8 & 2.2 & -8.1 & 2.9 & 0.2 & 0.1 & -0.4 & 0.2 & 10.7 \\
\hline Hamilton & 31081 & 11.8 & 4.9 & -10.6 & 2.5 & 0.7 & 0.3 & -0.6 & 0.1 & 12.7 \\
\hline Harlan & 31083 & 0.4 & 0.9 & -2.5 & 1.3 & 0.0 & 0.1 & -0.2 & 0.1 & 4.9 \\
\hline
\end{tabular}


Table 1-1. Area-weighted, average water-level changes and changes in water in storage in the High Plains aquifer, 1980 to 1995,1995 to 2000, 2000 to 2005, and 2005 to 2009, and water in storage in the High Plains aquifer, 2009, by county, within State.-Continued

[FIPS, Federal Information Processing Standard; ft, feet; acre-ft, acre-feet]

\begin{tabular}{|c|c|c|c|c|c|c|c|c|c|c|}
\hline \multirow{2}{*}{ County } & \multirow{2}{*}{$\begin{array}{l}\text { FIPS } \\
\text { state } \\
\text { and } \\
\text { county } \\
\text { code }\end{array}$} & \multicolumn{4}{|c|}{$\begin{array}{l}\text { Area-weighted, average water-level change, } \\
\text { in } \mathrm{ft}\end{array}$} & \multicolumn{4}{|c|}{$\begin{array}{l}\text { Changes in water in storage, } \\
\text { in million acre-ft }\end{array}$} & \multirow{2}{*}{$\begin{array}{c}\text { Water in } \\
\text { storage, } \\
2009, \\
\text { in million } \\
\text { acre-ft }\end{array}$} \\
\hline & & $\begin{array}{l}1980 \text { to } \\
1995\end{array}$ & $\begin{array}{l}1995 \text { to } \\
2000\end{array}$ & $\begin{array}{l}2000 \text { to } \\
2005\end{array}$ & $\begin{array}{c}2005 \text { to } \\
2009\end{array}$ & $\begin{array}{l}1980 \text { to } \\
1995\end{array}$ & $\begin{array}{l}1995 \text { to } \\
2000\end{array}$ & $\begin{array}{l}2000 \text { to } \\
2005\end{array}$ & $\begin{array}{l}2005 \text { to } \\
2009\end{array}$ & \\
\hline \multicolumn{11}{|c|}{ Nebraska-Continued } \\
\hline Hayes & 31085 & -0.1 & -0.3 & -4.2 & -0.5 & 0.0 & 0.0 & -0.3 & 0.0 & 14.9 \\
\hline Hitchcock & 31087 & 0.0 & -0.2 & -1.2 & -0.3 & 0.0 & 0.0 & -0.1 & 0.0 & 4.9 \\
\hline Holt & 31089 & 1.6 & -0.9 & -2.7 & 2.1 & 0.3 & -0.2 & -0.6 & 0.4 & 74.4 \\
\hline Hooker & 31091 & 4.9 & 0.6 & -0.1 & -1.0 & 0.4 & 0.0 & 0.0 & -0.1 & 63.2 \\
\hline Howard & 31093 & 3.1 & -0.2 & -2.9 & 2.3 & 0.1 & 0.0 & -0.2 & 0.1 & 12.5 \\
\hline Jefferson & 31095 & 0.7 & 1.7 & -4.0 & 0.0 & 0.0 & 0.0 & -0.1 & 0.0 & 3.5 \\
\hline Kearney & 31099 & 3.8 & 1.8 & -6.6 & 1.4 & 0.2 & 0.1 & -0.4 & 0.1 & 14.9 \\
\hline Keith & 31101 & -0.7 & 0.5 & -2.2 & -1.5 & -0.1 & 0.1 & -0.3 & -0.1 & 22.8 \\
\hline Keya Paha & 31103 & 1.0 & 1.6 & -2.3 & 0.4 & 0.0 & 0.1 & -0.1 & 0.0 & 5.6 \\
\hline Kimball & 31105 & 0.0 & 0.2 & -2.3 & -1.9 & 0.0 & 0.0 & -0.2 & -0.1 & 8.3 \\
\hline Knox & 31107 & 2.3 & 0.2 & -1.6 & 0.7 & 0.1 & 0.0 & 0.0 & 0.0 & 2.2 \\
\hline Lincoln & 31111 & -0.1 & 0.6 & -2.9 & -0.6 & 0.0 & 0.2 & -0.7 & -0.2 & 105.5 \\
\hline Logan & 31113 & 0.9 & 0.4 & -1.7 & -0.8 & 0.1 & 0.0 & -0.1 & 0.0 & 34.4 \\
\hline Loup & 31115 & 0.9 & 0.8 & -1.0 & 0.9 & 0.0 & 0.0 & -0.1 & 0.0 & 29.7 \\
\hline McPherson & 31117 & 1.4 & 1.5 & -0.2 & -0.8 & 0.1 & 0.1 & 0.0 & -0.1 & 63.6 \\
\hline Madison & 31119 & 5.0 & 0.2 & -2.4 & 4.5 & 0.3 & 0.0 & -0.1 & 0.3 & 13.1 \\
\hline Merrick & 31121 & 0.5 & -0.2 & -5.0 & 3.4 & 0.0 & 0.0 & -0.2 & 0.2 & 6.6 \\
\hline Morrill & 31123 & -0.2 & -0.2 & -1.8 & -0.3 & 0.0 & 0.0 & -0.2 & 0.0 & 28.4 \\
\hline Nance & 31125 & 3.4 & 0.4 & -2.8 & 2.3 & 0.1 & 0.0 & -0.1 & 0.1 & 5.1 \\
\hline Nuckolls & 31129 & 1.0 & 0.4 & -2.0 & 0.4 & 0.1 & 0.0 & -0.1 & 0.0 & 2.2 \\
\hline Perkins & 31135 & -7.9 & 0.3 & -7.8 & -5.0 & -0.7 & 0.0 & -0.6 & -0.4 & 18.6 \\
\hline Phelps & 31137 & 8.0 & 2.4 & -4.6 & 1.9 & 0.5 & 0.1 & -0.3 & 0.1 & 15.5 \\
\hline Pierce & 31139 & 5.1 & -0.9 & -3.2 & 3.6 & 0.3 & 0.0 & -0.2 & 0.2 & 11.1 \\
\hline Platte & 31141 & 3.0 & 0.4 & -5.4 & 3.3 & 0.2 & 0.0 & -0.4 & 0.2 & 9.4 \\
\hline Polk & 31143 & 9.6 & 0.2 & -8.4 & 1.4 & 0.4 & 0.0 & -0.4 & 0.1 & 9.2 \\
\hline Red Willow & 31145 & 0.2 & -0.2 & -2.5 & 0.0 & 0.0 & 0.0 & -0.2 & 0.0 & 4.2 \\
\hline Rock & 31149 & 2.0 & -0.6 & -2.9 & 1.7 & 0.2 & -0.1 & -0.3 & 0.2 & 52.1 \\
\hline Saline & 31151 & 1.3 & 0.9 & -4.8 & 0.5 & 0.1 & 0.1 & -0.2 & 0.0 & 6.4 \\
\hline Saunders & 31155 & 0.0 & 0.0 & 0.0 & 0.0 & 0.0 & 0.0 & 0.0 & 0.0 & 0.0 \\
\hline Scotts Bluff & 31157 & 0.0 & -0.2 & -2.9 & 0.8 & 0.0 & 0.0 & -0.1 & 0.0 & 6.6 \\
\hline Seward & 31159 & 5.2 & 1.1 & -6.8 & 0.9 & 0.2 & 0.0 & -0.2 & 0.0 & 7.3 \\
\hline Sheridan & 31161 & -0.5 & 0.7 & -2.0 & -0.2 & -0.1 & 0.1 & -0.4 & 0.0 & 82.9 \\
\hline Sherman & 31163 & 2.9 & 0.3 & -2.3 & 0.7 & 0.1 & 0.0 & -0.1 & 0.0 & 20.5 \\
\hline Sioux & 31165 & 0.0 & -0.3 & -0.5 & 0.2 & 0.0 & 0.0 & -0.1 & 0.0 & 43.6 \\
\hline Stanton & 31167 & 3.9 & -0.9 & -3.6 & 2.6 & 0.1 & 0.0 & -0.1 & 0.1 & 4.5 \\
\hline Thayer & 31169 & 0.9 & 0.3 & -3.6 & 0.3 & 0.0 & 0.0 & -0.2 & 0.0 & 6.2 \\
\hline Thomas & 31171 & 1.1 & 0.4 & -0.3 & -1.4 & 0.1 & 0.0 & 0.0 & -0.1 & 44.1 \\
\hline Thurston & 31173 & 3.3 & 0.4 & -0.3 & 0.6 & 0.0 & 0.0 & 0.0 & 0.0 & 0.0 \\
\hline
\end{tabular}


Table 1-1. Area-weighted, average water-level changes and changes in water in storage in the High Plains aquifer, 1980 to 1995,1995 to 2000, 2000 to 2005, and 2005 to 2009, and water in storage in the High Plains aquifer, 2009, by county, within State.-Continued

[FIPS, Federal Information Processing Standard; ft, feet; acre-ft, acre-feet]

\begin{tabular}{|c|c|c|c|c|c|c|c|c|c|c|}
\hline \multirow{2}{*}{ County } & \multirow{2}{*}{$\begin{array}{l}\text { FIPS } \\
\text { state } \\
\text { and } \\
\text { county } \\
\text { code }\end{array}$} & \multicolumn{4}{|c|}{$\begin{array}{l}\text { Area-weighted, average water-level change, } \\
\text { in } \mathrm{ft}\end{array}$} & \multicolumn{4}{|c|}{$\begin{array}{l}\text { Changes in water in storage, } \\
\text { in million acre-ft }\end{array}$} & \multirow{2}{*}{$\begin{array}{c}\text { Water in } \\
\text { storage, } \\
2009, \\
\text { in million } \\
\text { acre-ft }\end{array}$} \\
\hline & & $\begin{array}{l}1980 \text { to } \\
1995\end{array}$ & $\begin{array}{l}1995 \text { to } \\
2000\end{array}$ & $\begin{array}{l}2000 \text { to } \\
2005\end{array}$ & $\begin{array}{l}2005 \text { to } \\
2009\end{array}$ & $\begin{array}{l}1980 \text { to } \\
1995\end{array}$ & $\begin{array}{l}1995 \text { to } \\
2000\end{array}$ & $\begin{array}{l}2000 \text { to } \\
2005\end{array}$ & $\begin{array}{l}2005 \text { to } \\
2009\end{array}$ & \\
\hline \multicolumn{11}{|c|}{ Nebraska-Continued } \\
\hline Valley & 31175 & 4.6 & 2.4 & 0.3 & 1.8 & 0.2 & 0.1 & 0.0 & 0.1 & 27.8 \\
\hline Washington & 31177 & 0.0 & -0.1 & 0.0 & 0.0 & 0.0 & 0.0 & 0.0 & 0.0 & 0.0 \\
\hline Wayne & 31179 & 3.5 & -1.1 & -2.2 & 2.7 & 0.1 & 0.0 & -0.1 & 0.1 & 4.6 \\
\hline Webster & 31181 & 1.3 & 0.0 & -3.1 & 0.8 & 0.1 & 0.0 & -0.2 & 0.1 & 3.9 \\
\hline Wheeler & 31183 & 2.7 & 0.9 & -1.9 & 3.8 & 0.2 & 0.1 & -0.1 & 0.2 & 27.0 \\
\hline York & 31185 & 10.5 & 2.4 & -10.8 & 2.0 & 0.6 & 0.1 & -0.7 & 0.1 & 15.4 \\
\hline \multicolumn{11}{|c|}{ New Mexico } \\
\hline Chaves & 35005 & 0.0 & 0.0 & -0.1 & 0.0 & 0.0 & 0.0 & 0.0 & 0.0 & 0.3 \\
\hline Curry & 35009 & -6.6 & -2.3 & -2.0 & -0.4 & -0.9 & -0.3 & -0.3 & -0.1 & 6.3 \\
\hline DeBaca & 35011 & 0.0 & 0.0 & 0.0 & 0.0 & 0.0 & 0.0 & 0.0 & 0.0 & 0.0 \\
\hline Eddy & 35015 & 0.0 & 0.0 & -1.3 & 0.0 & 0.0 & 0.0 & 0.0 & 0.0 & 0.0 \\
\hline Guadalupe & 35019 & 0.0 & 0.0 & 0.0 & 0.0 & 0.0 & 0.0 & 0.0 & 0.0 & 0.0 \\
\hline Harding & 35021 & 0.0 & 0.0 & 0.0 & 0.0 & 0.0 & 0.0 & 0.0 & 0.0 & 0.2 \\
\hline Lea & 35025 & -1.2 & -1.9 & -1.5 & -1.9 & -0.2 & -0.4 & -0.3 & -0.4 & 17.2 \\
\hline Quay & 35037 & -0.1 & 0.2 & -0.7 & 0.1 & 0.0 & 0.0 & 0.0 & 0.0 & 1.4 \\
\hline Roosevelt & 35041 & -6.4 & -3.0 & -2.2 & -0.1 & -0.8 & -0.4 & -0.3 & 0.0 & 3.4 \\
\hline Union & 35059 & -2.2 & -1.4 & -2.5 & -0.8 & -0.1 & -0.1 & -0.1 & 0.0 & 2.3 \\
\hline \multicolumn{11}{|c|}{ Oklahoma } \\
\hline Beaver & 40007 & 0.1 & -0.2 & 0.0 & -0.3 & 0.0 & 0.0 & 0.0 & -0.1 & 21.8 \\
\hline Beckham & 40009 & 0.0 & 0.0 & 0.0 & 0.0 & 0.0 & 0.0 & 0.0 & 0.0 & 0.0 \\
\hline Cimarron & 40025 & -1.9 & -2.2 & -0.4 & -0.9 & -0.3 & -0.3 & -0.1 & -0.1 & 9.3 \\
\hline Dewey & 40043 & 0.0 & 0.0 & 0.0 & 0.0 & 0.0 & 0.0 & 0.0 & 0.0 & 0.0 \\
\hline Ellis & 40045 & 1.4 & 2.9 & 1.5 & 0.1 & 0.2 & 0.4 & 0.2 & 0.0 & 13.2 \\
\hline Harper & 40059 & 0.7 & 0.3 & -0.1 & -0.4 & 0.0 & 0.0 & 0.0 & 0.0 & 0.9 \\
\hline Roger Mills & 40129 & 0.3 & 0.5 & 0.3 & -0.1 & 0.0 & 0.0 & 0.0 & 0.0 & 1.8 \\
\hline Texas & 40139 & -8.0 & -6.3 & -2.5 & -3.7 & -1.7 & -1.4 & -0.5 & -0.8 & 39.5 \\
\hline Woodward & 40153 & 0.5 & 1.2 & -0.1 & -0.3 & 0.0 & 0.1 & 0.0 & 0.0 & 4.1 \\
\hline \multicolumn{11}{|c|}{ South Dakota } \\
\hline Bennett & 46007 & 0.3 & 2.0 & -1.6 & -0.4 & 0.0 & 0.1 & -0.1 & 0.0 & 30.7 \\
\hline Gregory & 46053 & 0.0 & 1.1 & -0.8 & 0.0 & 0.0 & 0.0 & 0.0 & 0.0 & 0.3 \\
\hline Jackson & 46071 & 0.0 & 0.1 & -0.8 & -0.2 & 0.0 & 0.0 & 0.0 & 0.0 & 2.5 \\
\hline Mellette & 46095 & 0.3 & 0.9 & -1.2 & 0.0 & 0.0 & 0.0 & 0.0 & 0.0 & 0.0 \\
\hline Shannon & 46113 & 0.0 & 0.4 & 0.0 & 0.1 & 0.0 & 0.0 & 0.0 & 0.0 & 10.4 \\
\hline Todd & 46121 & 0.0 & 0.7 & -0.3 & -0.6 & 0.0 & 0.1 & 0.0 & -0.1 & 15.6 \\
\hline Tripp & 46123 & 0.0 & 0.0 & -0.6 & 0.0 & 0.0 & 0.0 & 0.0 & 0.0 & 1.6 \\
\hline \multicolumn{11}{|c|}{ Texas } \\
\hline Andrews & 48003 & 2.3 & 0.9 & 0.5 & -1.3 & 0.3 & 0.1 & 0.0 & -0.2 & 3.2 \\
\hline Armstrong & 48011 & -1.9 & 1.4 & -0.2 & -0.1 & -0.1 & 0.1 & 0.0 & 0.0 & 3.6 \\
\hline
\end{tabular}


Table 1-1. Area-weighted, average water-level changes and changes in water in storage in the High Plains aquifer, 1980 to 1995,1995 to 2000, 2000 to 2005, and 2005 to 2009, and water in storage in the High Plains aquifer, 2009, by county, within State.-Continued

[FIPS, Federal Information Processing Standard; ft, feet; acre-ft, acre-feet]

\begin{tabular}{|c|c|c|c|c|c|c|c|c|c|c|}
\hline \multirow{2}{*}{ County } & \multirow{2}{*}{$\begin{array}{l}\text { FIPS } \\
\text { state } \\
\text { and } \\
\text { county } \\
\text { code }\end{array}$} & \multicolumn{4}{|c|}{$\begin{array}{l}\text { Area-weighted, average water-level change, } \\
\text { in } \mathrm{ft}\end{array}$} & \multicolumn{4}{|c|}{$\begin{array}{c}\text { Changes in water in storage, } \\
\text { in million acre-ft }\end{array}$} & \multirow{2}{*}{$\begin{array}{c}\text { Water in } \\
\text { storage, } \\
2009, \\
\text { in million } \\
\text { acre-ft }\end{array}$} \\
\hline & & $\begin{array}{l}1980 \text { to } \\
1995\end{array}$ & $\begin{array}{l}1995 \text { to } \\
2000\end{array}$ & $\begin{array}{l}2000 \text { to } \\
2005\end{array}$ & $\begin{array}{l}2005 \text { to } \\
2009\end{array}$ & $\begin{array}{l}1980 \text { to } \\
1995\end{array}$ & $\begin{array}{l}1995 \text { to } \\
2000\end{array}$ & $\begin{array}{l}2000 \text { to } \\
2005\end{array}$ & $\begin{array}{l}2005 \text { to } \\
2009\end{array}$ & \\
\hline \multicolumn{11}{|c|}{ Texas-Continued } \\
\hline Bailey & 48017 & -4.6 & -4.8 & -1.9 & -1.5 & -0.4 & -0.4 & -0.2 & -0.1 & 4.6 \\
\hline Borden & 48033 & 0.6 & 0.0 & -0.3 & 0.2 & 0.0 & 0.0 & 0.0 & 0.0 & 0.1 \\
\hline Briscoe & 48045 & -3.4 & -1.2 & 0.2 & -0.1 & -0.1 & 0.0 & 0.0 & 0.0 & 1.4 \\
\hline Carson & 48065 & -11.9 & 0.2 & -1.6 & -0.9 & -1.1 & 0.0 & -0.2 & -0.1 & 14.4 \\
\hline Castro & 48069 & -23.2 & -12.0 & -9.3 & -7.0 & -2.3 & -1.2 & -0.9 & -0.7 & 7.6 \\
\hline Cochran & 48079 & 2.2 & -3.7 & -2.1 & -1.6 & 0.2 & -0.3 & -0.2 & -0.1 & 3.9 \\
\hline Collingsworth & 48087 & 0.0 & 0.0 & 0.0 & 0.0 & 0.0 & 0.0 & 0.0 & 0.0 & 0.0 \\
\hline Crosby & 48107 & -1.7 & -4.6 & 0.0 & -1.4 & -0.1 & -0.3 & 0.0 & -0.1 & 4.8 \\
\hline Dallam & 48111 & -8.9 & -8.4 & -8.0 & -4.4 & -1.5 & -1.4 & -1.3 & -0.8 & 16.4 \\
\hline Dawson & 48115 & 17.6 & -7.3 & -3.1 & -1.5 & 1.4 & -0.6 & -0.3 & -0.1 & 4.5 \\
\hline Deaf Smith & 48117 & -7.7 & -3.1 & -0.4 & -2.0 & -1.2 & -0.5 & -0.1 & -0.3 & 9.0 \\
\hline Dickens & 48125 & -3.4 & -0.5 & 1.0 & -0.2 & 0.0 & 0.0 & 0.0 & 0.0 & 0.1 \\
\hline Donley & 48129 & 0.9 & 0.8 & -0.9 & 0.0 & 0.1 & 0.1 & -0.1 & 0.0 & 4.3 \\
\hline Ector & 48135 & 0.0 & 0.0 & 0.0 & 0.0 & 0.0 & 0.0 & 0.0 & 0.0 & 0.1 \\
\hline Floyd & 48153 & -11.1 & -5.1 & -1.2 & -1.5 & -1.2 & -0.5 & -0.1 & -0.2 & 7.7 \\
\hline Gaines & 48165 & 1.5 & -8.9 & -6.4 & -4.6 & 0.2 & -1.3 & -0.9 & -0.7 & 6.2 \\
\hline Garza & 48169 & 7.1 & -1.1 & -1.2 & 0.1 & 0.1 & 0.0 & 0.0 & 0.0 & 0.2 \\
\hline Glasscock & 48173 & 6.9 & -1.5 & -0.6 & 1.6 & 0.2 & 0.0 & 0.0 & 0.0 & 0.6 \\
\hline Gray & 48179 & -3.3 & 1.8 & 0.0 & 0.1 & -0.3 & 0.2 & 0.0 & 0.0 & 11.2 \\
\hline Hale & 48189 & -22.3 & -10.8 & -7.4 & -5.7 & -2.4 & -1.1 & -0.8 & -0.6 & 6.4 \\
\hline Hall & 48191 & 0.0 & 0.0 & 0.0 & 0.0 & 0.0 & 0.0 & 0.0 & 0.0 & 0.0 \\
\hline Hansford & 48195 & -16.6 & -6.8 & -3.6 & -9.5 & -1.7 & -0.7 & -0.4 & -0.9 & 19.7 \\
\hline Hartley & 48205 & -9.1 & -14.8 & -8.6 & -5.8 & -1.5 & -2.4 & -1.4 & -1.0 & 18.6 \\
\hline Hemphill & 48211 & 0.3 & 0.5 & -0.7 & 1.8 & 0.0 & 0.0 & -0.1 & 0.2 & 15.7 \\
\hline Hockley & 48219 & 1.2 & -3.1 & -2.3 & -1.2 & 0.1 & -0.3 & -0.2 & -0.1 & 3.6 \\
\hline Howard & 48227 & 4.5 & -5.4 & 0.4 & 0.5 & 0.3 & -0.3 & 0.0 & 0.0 & 2.2 \\
\hline Hutchinson & 48233 & -7.9 & -4.5 & -4.1 & -4.3 & -0.6 & -0.4 & -0.3 & -0.3 & 7.0 \\
\hline Lamb & 48279 & -16.1 & -7.7 & -6.0 & -5.0 & -1.8 & -0.9 & -0.7 & -0.6 & 6.6 \\
\hline Lipscomb & 48295 & 0.4 & -4.1 & 1.7 & -0.1 & 0.0 & -0.4 & 0.2 & 0.0 & 22.8 \\
\hline Lubbock & 48303 & 0.3 & -3.3 & -1.6 & -0.7 & 0.1 & -0.3 & -0.1 & -0.1 & 5.2 \\
\hline Lynn & 48305 & 9.2 & -3.0 & -1.1 & 1.8 & 0.7 & -0.3 & -0.1 & 0.1 & 3.4 \\
\hline Martin & 48317 & 12.0 & -3.4 & 1.4 & -2.0 & 1.1 & -0.3 & 0.1 & -0.2 & 5.9 \\
\hline Midland & 48329 & 4.6 & -2.8 & -0.5 & 0.7 & 0.2 & -0.1 & 0.0 & 0.0 & 1.9 \\
\hline Moore & 48341 & -15.0 & -7.1 & -4.4 & -8.8 & -1.3 & -0.6 & -0.4 & -0.7 & 6.9 \\
\hline Motley & 48345 & -0.6 & -0.7 & 0.2 & 0.0 & 0.0 & 0.0 & 0.0 & 0.0 & 0.1 \\
\hline Ochiltree & 48357 & -10.1 & -3.7 & -0.2 & -2.6 & -1.0 & -0.4 & 0.0 & -0.2 & 21.1 \\
\hline Oldham & 48359 & 0.7 & -0.1 & 0.3 & -1.0 & 0.0 & 0.0 & 0.0 & -0.1 & 1.7 \\
\hline Parmer & 48369 & -24.8 & -12.6 & -8.4 & -7.5 & -2.6 & -1.3 & -0.9 & -0.8 & 6.6 \\
\hline
\end{tabular}


Table 1-1. Area-weighted, average water-level changes and changes in water in storage in the High Plains aquifer, 1980 to 1995,1995 to 2000, 2000 to 2005, and 2005 to 2009, and water in storage in the High Plains aquifer, 2009, by county, within State.-Continued

[FIPS, Federal Information Processing Standard; ft, feet; acre-ft, acre-feet]

\begin{tabular}{|c|c|c|c|c|c|c|c|c|c|c|}
\hline \multirow{2}{*}{ County } & \multirow{2}{*}{$\begin{array}{l}\text { FIPS } \\
\text { state } \\
\text { and } \\
\text { county } \\
\text { code }\end{array}$} & \multicolumn{4}{|c|}{$\begin{array}{l}\text { Area-weighted, average water-level change, } \\
\text { in } \mathrm{ft}\end{array}$} & \multicolumn{4}{|c|}{$\begin{array}{l}\text { Changes in water in storage, } \\
\text { in million acre-ft }\end{array}$} & \multirow{2}{*}{$\begin{array}{c}\text { Water in } \\
\text { storage, } \\
2009, \\
\text { in million } \\
\text { acre-ft }\end{array}$} \\
\hline & & $\begin{array}{l}1980 \text { to } \\
1995\end{array}$ & $\begin{array}{l}1995 \text { to } \\
2000\end{array}$ & $\begin{array}{l}2000 \text { to } \\
2005\end{array}$ & $\begin{array}{l}2005 \text { to } \\
2009\end{array}$ & $\begin{array}{l}1980 \text { to } \\
1995\end{array}$ & $\begin{array}{l}1995 \text { to } \\
2000\end{array}$ & $\begin{array}{l}2000 \text { to } \\
2005\end{array}$ & $\begin{array}{l}2005 \text { to } \\
2009\end{array}$ & \\
\hline \multicolumn{11}{|c|}{ Texas-Continued } \\
\hline Potter & 48375 & -0.9 & 0.0 & 0.3 & 0.0 & 0.0 & 0.0 & 0.0 & 0.0 & 1.8 \\
\hline Roberts & 48393 & -2.1 & 2.6 & 0.1 & -2.4 & -0.2 & 0.2 & 0.0 & -0.2 & 22.2 \\
\hline Sherman & 48421 & -17.6 & -12.1 & -5.3 & -9.6 & -1.7 & -1.2 & -0.5 & -0.9 & 15.2 \\
\hline Swisher & 48437 & -4.9 & -3.2 & -1.4 & -1.4 & -0.5 & -0.3 & -0.2 & -0.1 & 4.8 \\
\hline Terry & 48445 & 7.0 & -8.0 & -5.3 & -0.3 & 0.5 & -0.6 & -0.4 & 0.0 & 3.8 \\
\hline Wheeler & 48483 & 0.3 & 0.9 & -0.4 & -0.3 & 0.0 & 0.1 & 0.0 & 0.0 & 8.2 \\
\hline Converse & 56009 & 0.0 & 0.0 & 0.0 & 0.0 & 0.0 & 0.0 & 0.0 & 0.0 & 0.3 \\
\hline Goshen & 56015 & -0.1 & 0.0 & -0.1 & 0.0 & 0.0 & 0.0 & 0.0 & 0.0 & 24.2 \\
\hline Laramie & 56021 & -0.5 & 0.1 & -1.4 & -0.6 & -0.1 & 0.0 & -0.2 & -0.1 & 28.0 \\
\hline Niobrara & 56027 & -0.3 & 0.0 & -0.5 & -0.5 & 0.0 & 0.0 & 0.0 & 0.0 & 11.5 \\
\hline Platte & 56031 & -0.1 & 0.2 & -0.7 & -0.5 & 0.0 & 0.0 & -0.1 & 0.0 & 14.7 \\
\hline
\end{tabular}




\section{Publishing support provided by:}

Rolla Publishing Service Center

For more information concerning this publication, contact: Director, USGS Nebraska Water Science Center 5231 South 19th Street Lincoln, Nebraska 68512

(402) 328-4100

Or visit the Nebraska Water Science Center Web site at: http://ne.water.usgs.gov/ 


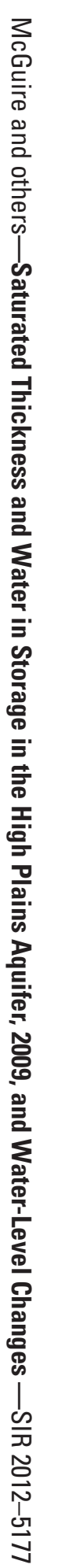

